\title{
Culture, institutions and democratization*
}

\author{
Yuriy Gorodnichenko ${ }^{1} \cdot$ Gerard Roland ${ }^{1}$
}

Received: 14 January 2020 / Accepted: 10 April 2020 / Published online: 23 April 2020

(c) Springer Science+Business Media, LLC, part of Springer Nature 2020

\begin{abstract}
We construct a model of revolution and transition to democracy under individualistic and collectivist cultures. The main result is that, despite facing potentially more challenging collective action problems, countries with individualistic cultures are more likely to end up adopting democracy earlier than countries with collectivist cultures. Our empirical analysis suggests a strong and robust association between individualistic cultures and average polity scores and durations of democracy, even after controlling for other determinants of democracy emphasized in the literature. We provide evidence that countries with collectivist cultures also are more likely to experience autocratic breakdowns and transitions from autocracy to autocracy.
\end{abstract}

Keywords Culture $\cdot$ Individualism $\cdot$ Collectivism $\cdot$ Democratization $\cdot$ Collective action

JEL Classification $\mathrm{H} 1 \cdot \mathrm{P} 48 \cdot \mathrm{Z} 1$

\section{Introduction}

Janos Kornai's work on economic systems does not ignore the role of political institutions. Whereas in Economics of Shortage, he mentioned paternalism as the source of soft budget constraints, in his later, more complete contribution (written under conditions of freedom) The Socialist System: The Political Economy of Communism, he mentioned communist party rule as the source and pillar of the socialist economic system and its phenomena. When discussing the success of Chinese economic reforms, especially in comparison

Gerard Roland

groland@econ.berkeley.edu

Yuriy Gorodnichenko

ygorodni@econ.berkeley.edu

1 University of California Berkeley, Berkeley, USA 
with the less spectacular economic reforms that took place in Central and Eastern Europe, Kornai emphasized the fundamental role of freedom and democracy that was absent in China despite the growth miracle. ${ }^{1}$ Nevertheless, he never discussed why China did not become a democracy. Furthermore, the experience of China (but also Vietnam, Singapore or even Thailand) appears to challenge modernization theory (Lipset 1959; Przeworski and Limongi 1997) according to which countries tend to become, or remain, democracies as they develop economically.

To put that puzzle in a perspective, we note that, according to Freedom House (1999), no single liberal democracy with universal suffrage existed in the world in 1900. By 2000, 120 of the world's 192 nations were liberal democracies. Recent developments tend to suggest that it is far from clear whether worldwide convergence towards democracy will continue. Autocratic tendencies have appeared in democratic countries such as Russia, Turkey, Hungary and Poland, to name a few. ${ }^{2}$ A key question is whether China, the biggest country in the world with miraculous growth over the last four decades, will evolve towards democracy. So far, to put it mildly, little evidence points in that direction. Reasons thus can be found for being skeptical that countries should all become democratic as they develop economically. Could modernization theories have overlooked slow-moving forces such as culture that may facilitate or hamper transition to democracy? Strikingly, although culture often is considered a bedrock of many social and economic processes, the role of culture in democratization largely has been ignored until now.

In this paper, we present a simple formal model of democratization that includes the individualistic-collectivist dimension of culture. A key difference between those cultural types is that a collectivist culture creates stronger pressure towards conformity and stronger aversion for radical institutional innovation. We show that, starting from an initial situation of autocracy, a collectivist society is less likely to adopt a democratic regime than an individualistic society, irrespective of whether a collectivist culture may be more effective in overcoming collective action problems. In our model, collectivist societies often end up in equilibrium having a "good" autocracy, i.e., an autocracy that does not act in a predatory way toward its citizens because good autocracies tend not to be overthrown by collectivist societies, unlike those of individualistic societies. That outcome occurs because of the stronger aversion for radical institutional innovation in collectivist societies. Furthermore, if political institutions can influence culture over time, our central prediction continues to hold: collectivist societies are less likely to end up with democracy. Note that those results do not follow automatically from a congruence between individualistic values and democracy. Countries with individualistic cultures must still overcome collective action problems to transition from autocracy to democracy, which is a non-trivial barrier. Indeed, we do observe countries with relatively high individualism scores and low democracy scores (e.g., Morocco). Yet, a striking result of our model is that even if one assumes that the collective action problem is much more acute in individualistic societies, such societies are still more likely to end up with democracy over time than collectivist societies.

\footnotetext{
1 This point is reiterated in his remarks at the occasion of the symposium for his 90th birthday; see Kornai (2018).

${ }^{2}$ Kornai has been a keen observer of such tendencies in the post-socialist world. Kornai (2016) describes in detail the changes made by Orban to Hungary's political and economic system. Kornai (2015) draws a distinction between autocracy and dictatorship, wherein the former lies between democracy and dictatorship, a distinction usually not made.
} 
We test the predictions of the model empirically, using the well-known Hofstede measure of individualism-collectivism. We find a strong and robust effect of individualism on average polity scores between 1980 and 2010. A one standard deviation increase in the individualism score is associated with as much as a four-point increase in polity scores, a large magnitude. That result holds even when we control for all of the variables that have been used in the literature on democratization, including measures of economic development. We also document evidence that countries with collectivist cultures experience autocratic breakdowns more frequently, suggesting less collective action failure in collectivist cultures. We do find strong evidence that in collectivist cultures, conditional on autocratic breakdown, transition to autocracy is more likely while in individualistic cultures, transition to democracy is more likely. While the main result is tested using the well-known polity data, those last results are tested using the new data on autocracies and autocratic transitions assembled by Geddes et al. (2014). Interestingly, other cultural variables, such as trust or other cultural dimensions constructed by Hofstede (2001) - power distance, uncertainty avoidance, masculinity, long-term orientation-do not have a significant or a robust effect on average polity scores, whereas the effect of individualism is very robust.

Because two-way causality may exist between democracy and culture, we apply instrumental variables to study the effect of culture on democratization. The first instrumental variable is a measure of historical pathogen prevalence. That variable has been argued (see, e.g., Fincher et al. 2008; Murray and Schaller 2010) to have a direct effect on the choice of collectivist culture as stronger pathogen prevalence created better survival prospects for communities that adopted more collectivist values, imposing stronger limits on individualistic behavior, being less open to foreigners and placing strong emphasis on tradition and stability of social norms. The second instrumental variable is a measure of genetic distance between countries based on differences in cross-sectional frequencies of blood types. That instrument is adopted as a proxy for vertical cultural transmission from parents to children. Since the genetic pool evolves relatively slowly and it is unlikely that neutral genetic markers (e.g., blood types) changed since the industrial revolution, one can use genetic distance in terms of such markers to instrument cultural differences. ${ }^{3}$ Because of the pitfalls related to cross-country regressions, we must be careful in interpreting the instrumental variable regression results as causal. Nevertheless, our findings are consistent with culture playing an important role in transitions from autocracy to democracy as well as in transitions from autocracy to autocracy.

\section{Contribution to the literature}

Our paper contributes to an immense body of work on the determinants of democratization. Since Lipset's (1959) seminal work, a large literature, both theoretical and empirical, has been devoted to understanding the determinants of democratization. Lipset emphasized

\footnotetext{
${ }^{3}$ More recently, some scholars have claimed to have found a direct link between genetic endowments and political behavior, such as political participation and ideology (Fowler et al. 2008; Hatemi and McDermott 2012). Those studies focus, however, on individual political behavior and individual political psychology, not on how average genetic endowments affect a collectivity or a country's culture. That difference is very important. The individual approach postulates a direct connection between an individual's genetic endowment and that individual's psychology or political behavior. In contrast, we use the correlation between cultural traits and genetic distance to address the potential endogeneity of culture.
} 
the role of economic development and, thus, not surprisingly, most disputes on democratization have been about whether economic development is a fundamental determinant of democracy. Lipset was taking a broad view of economic and social modernization creating conditions for increases in the demand for democracy. In recent years, debates about the importance of economic development have been revived after the work of Przeworski and Limongi (1997). Using data between 1950 and 1990 for 135 countries, they showed that the correlation between income and democracy was explained not so much by economic development leading to democratization, but rather by the fact that once countries have achieved a certain level of economic development, they usually never revert to authoritarian regimes. Countries could opt for democratic or dictatorial regimes for reasons that are unrelated to economic development, but if richer countries develop stable democracies, one will see a strong correlation between income per capita and democracy. ${ }^{4}$ Acemoglu and Robinson (2006) argued that democratization mostly was an elite strategy to commit to redistributive transfers in response to revolutionary threats. ${ }^{5}$ Some of the recent studies question causation from development to democracy or even the correlation between the two. Acemoglu et al. $(2005,2008)$ showed that the relationship between income (or education) and democracy, mainly is a feature of cross-sectional data and that when performing panel data analysis, one ceases to find a significant relationship between those variables. ${ }^{6}$ Acemoglu et al. (2014) in recent work even found that democracy affects growth, a conclusion opposite to that of modernization theory. On the other hand, Boix and Stokes (2003) found that by taking data far enough into the past (to the second half of the nineteenth century), one can recover a significant relation between income per capita and democracy. Treisman (2012) also found an effect of economic development in the medium to long run, with democratic transitions happening more often after the exit of a dictator.

To find a mention of cultural determinants of democracy, one has to go back to Almond and Verba (1963), who emphasized the importance of civic culture as a prerequisite for democracy in a comparative study of five countries (Italy, Germany, the United States, the United Kingdom and Mexico). Inglehart (2002) and, more recently, Inglehart and Weizel (2005), using the World Values Survey, argued that modernization leads to changes in values towards more self-expression and stronger emphasis on individual liberty. ${ }^{7}$ According to them, those changes in values underlie stronger support for democracy. Their study is the closest to ours because the values they emphasize are close to individualism as we define it (more on that below). However, their focus is not the effect of culture on democracy. Instead, they emphasize cultural changes brought about by modernization. Our approach is different: we take culture as slow-moving (Roland 2004), ${ }^{8}$ thus potentially

\footnotetext{
${ }^{4}$ Persson and Tabellini (2009) specified a theoretical model and showed empirical support for a theory of positive feedback between the capital stock of democratic experience and economic development. Persson (2005) showed that the form of democracy mattered for income growth: the introduction of parliamentary democracy with proportional electoral rules produced the most growth-promoting policies.

${ }^{5}$ Bruckner and Ciccone (2011) found that transitory negative income shocks related to drought have a positive effect on democratization in Sub-Saharan Africa.

${ }^{6}$ Grosjean and Senik (2011) found no link between income and support for democracy in the context of transition countries.

7 See also Putnam et al. (1994) on how a strong culture of civil engagement affects the quality of government.

8 A large empirical literature shows that culture has a very strong inertia, from research showing the longrun effects of cultural differences between groups of early US settlers (see Fischer 1989; Grosjean 2014) to research showing the persistence of culture of ancestors' countries of origin among US immigrants (see, e.g., Guiso et al. 2006; Tabellini 2008; Algan and Cahuc 2010).
} 
affecting faster-moving variables, such as political institutions. We do not deny that culture may be affected by political institutions and other variables, which is why we try to isolate the effect of culture on political institutions by adopting an instrumental variables method. While our research suggests that individualism affects both income per capita and democracy, we do not rule out a separate effect of income on democracy. Furthermore, we document that, in contrast to other measures of culture (e.g., religion, trust), individualism is a robust predictor of democracy. To the best of our knowledge, our paper is the first to explore systematically how culture (individualism) can influence democratization processes.

The remainder of the paper is organized as follows. In Sect. 3, we present the model. In Sect. 4, we present the empirical analysis. Section 5 concludes.

\section{The model}

Our model embeds cultural differences in a model of democratization and revolution. Consider a polity composed of two classes of infinitely lived citizens: rich and poor. The size of the population is normalized to one. The rich are present in proportion $\delta<\frac{1}{2}$. The average income of the rich is $y^{R}=\theta y / \delta$, whereas the average income of the poor, present in proportion $1-\delta>\frac{1}{2}$, is $y^{P}=(1-\theta) y /(1-\delta)$, where $y$ is average income $\left(y=\delta y^{R}+(1-\delta) y^{P}\right)$ and $\theta(\geq 1 / 2)$ is an indicator of income inequality.

The initial regime is autocratic. We will make the distinction between good and bad autocrats. We assume that a bad autocrat acts in a predatory way and takes away all income from all citizens. Therefore, the after-tax income of the rich and poor is assumed to be equal to zero. Our assumptions represent a clear simplification of reality. ${ }^{9}$ We assume that a good autocrat does not tax or redistribute. That assumption likewise is not realistic but helps to distinguish a good from a bad autocrat, a distinction that is in our view important to make. In the model, everybody, rich and poor, prefers good autocrats to bad autocrats. A good autocrat is drawn randomly with probability $\alpha$ and bad autocrat with probability $(1-\alpha)$. We assume that a ruler stays in power forever unless a revolt succeeds in overthrowing him or her. ${ }^{10}$

In each period, citizens are able to overcome their collective action problem and to overthrow the ruler with probability $q_{k}$ ( $k=I$ for individualism or $k=C$ for collectivism). We do not need the results below to make any particular assumptions about the ranking of $q_{k}$ between different cultures. A natural assumption might be $q_{C}>q_{I}$ : a collectivist culture can help overcome free-rider problems if a social norm exists of just revolt against an unjust autocratic ruler. Indeed, people in a collectivist culture will conform to the social norm and derive social status or other rewards from doing so (failure to conform may lead to being ostracized). On the other hand, one also can make an argument that $q_{C}<q_{I}$. In collectivist societies, allegiances are based on tribal or clan affiliation. If various tribes or clans deeply distrust one another and are in conflict, they may have a more difficult time overcoming collective action problems than people in those individualistic cultures that have dense civil society networks and cultures of citizen participation.

\footnotetext{
9 On predatory states, see Vahabi (2016a, b). On differences between autocratic regimes, see the distinction made by McGuire and Olson (1996) on roving bandits versus stationary bandits.

10 See Tullock (1974) on the costs and benefits of revolts.
} 
In periods when citizens are able to overcome their collective action problems, usually called revolutionary conditions, citizens in all cultures may choose to overthrow the regime or to keep it. While it seems obvious that citizens will want to overthrow a bad autocrat, it is not a priori obvious that they want to replace a good autocrat.

Since the poor are in the majority, the decision to engage or not in collective action is theirs. Even if the rich would not want to engage in collective action, we assume that the decisions of the poor are the ones that matter. ${ }^{11}$ If they engage in collective action, they will either replace the old autocrat with a new, possibly good, autocrat or introduce a radical institutional innovation and replace autocracy with democracy. In case of successful collective action, it is assumed that an autocrat will be replaced, with probability $\sigma_{k}$, by another autocrat (possibly a good one, which happens with probability $\alpha$ ) and that he will be replaced by democracy with probability $\left(1-\sigma_{k}\right)$. We assume that $\sigma_{C}>\sigma_{I}$; that assumption will matter for our results. One justification for the assumption is that collectivist cultures have higher levels of conformism and lower propensities to engage in institutional innovations. Another, probably deeper, justification is that collectivist values place heavier emphasis on the difference between a benevolent ruler and a bad ruler, on political stability and the capacity of a good ruler wisely to arbitrate disputes between different clans and groups. In contrast, individualistic values emphasize individual freedom, equality of citizens before the law, and limited government. ${ }^{12}$

Note that in our model, uncertainty exists about what institutional regime will follow the decision to revolt. The only decision taken is to engage in collective action, but the outcome is uncertain. That aspect of the model seems quite realistic. For example, during the Arab Spring of 2011, it was not clear whether democratic regimes or new autocratic regimes with changed rulers were going to emerge. As of 2016, such uncertainty still not yet been fully resolved in various countries of the region. The assumption stated above about the values of $\sigma_{k}$ means that the uncertainty over the outcome of collective action is influenced by deep cultural parameters. Figure 1 summarizes the timing of actions and outcomes.

The main cultural differences in the model (differences in $q_{k}$ and $\sigma_{k}$ ) undoubtedly are in reduced form because existing theories of how collective action problems are overcome and theories of the dynamics of collective action are far from satisfactory. Nevertheless, the current model makes some progress in our knowledge of institutional change by introducing a cultural component into theories of revolution and democratization.

To simplify the algebra, we assume that once democracy is introduced, it remains in place forever. We thus rule out by assumption coups orchestrated by the rich to abolish democracy. ${ }^{13}$ Under democracy, the poor are in the majority and tax the rich. They are better off under democracy than under even a good autocratic ruler, whereas the rich generally will prefer the latter since no redistribution occurs under a good autocrat. Because the poor control a voting majority, only their decisions matter for the determination of the political

\footnotetext{
11 This part of the model should not be interpreted too literally. In many regime changes, some of the elite spearhead revolutions, coups and abrupt regime changes in the name of the people. Popular support for regime change is nevertheless critical for its success.

12 See Gorodnichenko and Roland (2012) for a fuller discussion of the cross-cultural differences between individualism and collectivism and their implications for economic and institutional behavior. Note also that liberal ideologies that defend democracy are based on individualist values.

13 Acemoglu and Robinson (2006) consider a model where the rich change the regime by a coup, and we do not incorporate that feature in this model so as not to introduce complications on an issue that has already been covered in the literature.
} 
regime and, hence, we can focus on the poor's decisions and value functions. The value function for income for the poor under democracy is:

$$
V_{D}=\frac{y^{P}+\tau *\left(y-y^{P}\right)-C(\tau) y}{1-\beta},
$$

where $y^{P}$ is the income of the poor, $\tau=\arg \max \left\{y^{P}+\tau *\left(y-y^{P}\right)-C(\tau) y\right\}$ and $C(\tau) y$ is the distortionary cost from redistributive taxation. The optimal tax rate thus is the one that maximizes the net income of the poor.

Under a predatory ruler, the poor always will prefer to revolt. However, under a good autocrat, the decision to revolt may lead to democracy with a certain probability, which makes the poor better off, but it may also lead to the installation of a predatory ruler.

Under a predatory ruler, the value function for the poor is:

$$
V_{B}=0+\beta\left\{q_{k} \sigma_{k}\left[\alpha V_{G}+(1-\alpha) V_{B}\right]+q_{k}\left(1-\sigma_{k}\right) V_{D}+\left(1-q_{k}\right) V_{B}\right\},
$$

where $B$ stands for the predatory, bad ruler and $G$ for the good ruler. In words, income is extracted from the poor today; in the future, with probability $q_{k}$ collective action is successful, in which case with probability $\sigma_{k}$ another autocratic regime (good or bad autocrat with probability $\alpha$ and $1-\alpha$ respectively) replaces it and, with probability $\left(1-\sigma_{k}\right)$, the sequel is democracy. Note that $V_{G}$ depends on whether the poor decide to revolt against a good autocrat. The value function for the poor under a good autocrat if they decide not to revolt $(N)$ is:

$$
V_{G N}=\frac{y^{P}}{1-\beta}
$$

whereas if they decide to revolt $(R)$, it is:

$$
V_{G R}=y^{P}+\beta\left\{q_{k} \sigma_{k}\left[\alpha V_{G R}+(1-\alpha) V_{B}\right]+q_{k}\left(1-\sigma_{k}\right) V_{D}+\left(1-q_{k}\right) V_{G R}\right\} .
$$

Note that the expression for $V_{G R}$ is similar to that of $V_{B}$. Indeed, we have that

$$
V_{G R}-V_{B}=y^{P}+\beta\left(1-q_{k}\right)\left(V_{G R}-V_{B}\right)=\frac{y^{P}}{1-\beta\left(1-q_{k}\right)} .
$$

We can then derive the following proposition.

Proposition 1 A threshold level $\bar{\sigma}_{k}<1$ exists, above which no revolutionary action is organized and below which revolutionary action always will be taken under a good ruler.

Proof of proposition 1 See the "Appendix".

Proposition 1 says that in a very collectivist culture (high $\sigma_{C}$ ), a revolt never will be mounted against a good autocrat, whereas in a very individualistic culture (low $\sigma_{I}$ ), revolution is certain. That result is interesting because, even if collectivist cultures were better able than individualistic cultures to overcome barriers to collective action, such organizational efforts would be trumped by stronger conformism (high $\sigma_{C}$ ).

The comparative statics likewise is interesting. By doing the appropriate calculations, one can see that when $\sigma_{k}$ is sufficiently high (close to 1 ), a larger $q_{k}$ will strengthen 


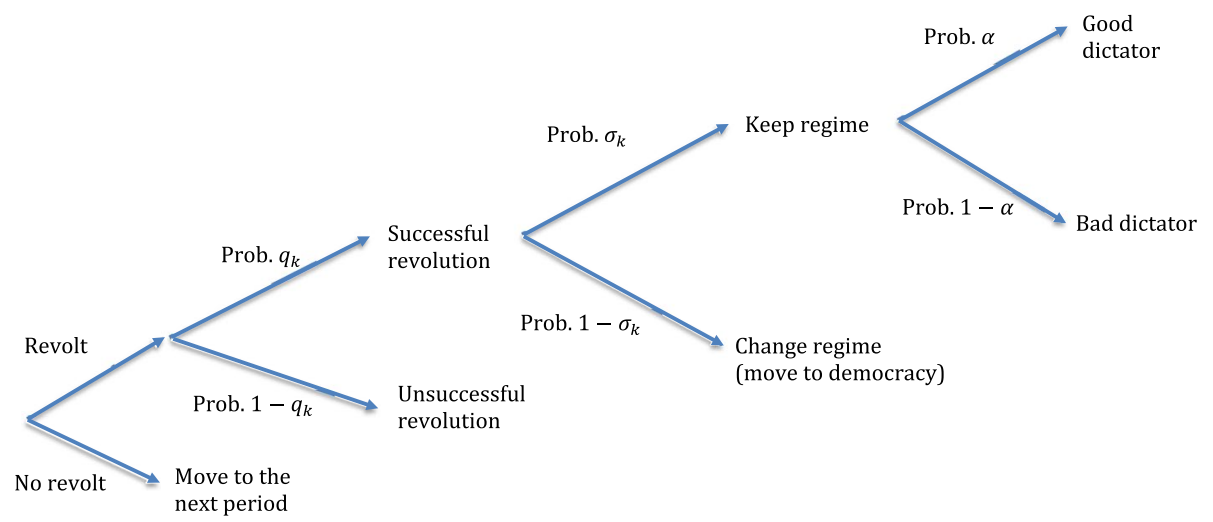

Fig. 1 Timing of events in the model

preferences against revolt, whereas when $\sigma_{k}$ is sufficiently low (close to 0), a larger $q_{k}$ will raise the expected payoffs from revolting. The latter result is intuitive but the former is surprising. It means that increases in the ability to overcome collective action problems lead to preferences against revolt when the degree of conformity is high. Intuitively, a tradeoff is involved in the decision to revolt. With some probability the revolt will lead to democracy, which will enhance poor's welfare, but with some probability, revolution will lead to a bad autocrat. When $q_{k}$ is high (and $\sigma_{k}$ is high), the latter becomes a more probable event.

Another comparative static result of the model is that less income inequality (low $\theta$ ) reduces the advantages of democracy over a good autocracy. In a fully egalitarian society with a good autocrat, the model generates no advantage from adopting democracy.

We can draw several other implications from this basic initial analysis. A first implication is that, if collectivist societies have larger $q \mathrm{~s}$, they will revolt more frequently when ruled by a bad autocrat. That conclusion follows because all cultures will revolt against bad autocrats, but collectivist cultures will better be able to overcome their collective action problems. In his famous History of Government from the Earliest Times, Finer (1997, pp. 523,799 ) observed that many more peasant revolts erupted in ancient China than in Europe in the pre-industrial world. While we do not have data good enough to test Finer's observation directly, it nevertheless is interesting and worth further examination. In the empirical section, we will use available data to examine collective action in different cultures. A second implication of the model is that, independent of the level of $q_{k}$, having a good autocrat in a collectivist society will lead to more regime stability under autocracy because of the dearth of revolts.

The main result we would like to test and what also is the most interesting one, follows from Proposition 1. More collectivist societies characterized by a high $\sigma$ tend not to revolt when they are ruled by a good autocrat. More individualistic societies characterized by a low $\sigma$ will tend to decide to revolt even if $q$ is very low. As a result, individualistic societies unambiguously are more likely to end up adopting democracy over time. That conclusion is expressed in Proposition 2: 
Proposition 2 Independently of the level of $q_{k}$, societies with a $\sigma_{k}$ less than $\bar{\sigma}_{k}$ have a strictly higher probability of ending up with democracy than societies with a higher $\sigma_{k}$, exceeding $\bar{\sigma}_{k}$, as long as $\alpha>0$.

Proof of proposition 2 See the "Appendix".

Intuitively, under a good autocrat, no revolt will be organized in a collectivist culture, in contrast to what is likely in an individualistic culture. The non-intuitive part of the proposition is that however small (but still non-zero) is $q_{k}$, individualistic cultures are more likely to end up with democracies. The reason is that collectivist societies will tend, with positive probability, to replace a bad autocrat with another autocrat rather than with democracy, as long as $\alpha>0$. If they get a good autocrat, they will not revolt again; if they are ruled by a bad autocrat, they will revolt but will, with positive probability, put another autocrat in place. However high $q_{C}$ is and however low $q_{I}$ is, the result of proposition 2 always holds.

In the model, culture is exogenous to institutions. What happens if we allow culture to be influenced by existing institutions? Suppose that we permit the cultural parameters of our model to change as a function of the length of time spent under a given regime. Indeed, Persson and Tabellini (2009) provide evidence that pro-democracy values are reinforced over time the longer people live under such a regime. Assume, thus, in the framework of our model, that $\sigma_{k}$ declines over time after democracy has been introduced. Assume also that $\sigma_{k}$ increases over time under a "good" autocratic regime and that those changes materialize only under peaceful conditions, i.e., under conditions wherein no revolt takes place. It follows that the results of our model will not change. Indeed, democracy and "good" autocracy are both absorbing states, depending on the values of $\sigma_{k}$. Once democracy has been reached, it will not be reversed; variations in $\sigma_{k}$ will not modify our conclusions. On the other hand, no revolt will occur under a good autocrat if $\sigma_{k}$ is above $\bar{\sigma}_{k}$. If living under a good autocrat increases $\sigma_{k}$ further, then no revolt against the good autocrat will be organized. The results of the model thus are unchanged if we allow culture to move slowly in such regimes. Note that while we cannot measure "good" and "bad' autocracies directly, we can test whether more collectivist societies tend to have more autocracy-to-autocracy transitions than autocracy-todemocracy transitions; we implement such a test in the empirical section.

Before turning to the data, it is useful to compare the predictions of our model with the results of mainstream models, such as that of Acemoglu and Robinson (2006). The current model shares certain basic features with the Acemoglu-Robinson model: two groups, the elite and the poor, are considered, a Markov structure is assumed, and the effect of income inequality is similar. The differences are, however, conceptually very substantial. In their model, relevant decisions are taken by the elite. In our model, decisions (to revolt or not) are taken by the mass of people, or their representatives within the elite, and uncertainty over the outcomes of collective action plays a much larger role. The Acemoglu-Robinson model incorporates absolutely no cultural component and the elites decide between either endogenously redistributing income to the poor when they threaten revolt, in order to avert a revolution, or to establish democracy as a credible commitment to redistribution. The probability of success of collective action plays an important role in their model. The more likely successful collective action is, the more likely it is that the elites will prefer to redistribute income to the poor to avoid a revolution. On the other hand, if that probability is lower, they will choose instead to establish 
democracy to avert a revolt. In contrast, in our model the collective action's probability of success $\left(q_{k}\right)$ does not play a significant role in determining long-term outcomes. It is instead the cultural parameter, $\sigma_{k}$ that determines the long-run probability that a country adopts democracy. Furthermore, to the extent that collective action is easier in collectivist cultures (we provide below some evidence consistent with that claim), our model predicts that a transition from autocracy to democracy is less likely in countries with collectivist cultures, which, as we discuss below is consistent with the data, while models in the Acemoglu-Robinson spirit predict the opposite result.

\section{Empirical analysis}

We now turn to the empirical analysis of the link between culture and democratization. Because we have no time series for our data on culture and, in particular, on individualism and collectivism. Moreover, because the available observations are at the country level, our empirical investigation will, by necessity, mostly be devoted to cross-country analysis.

\subsection{Data}

We take the Polity IV index averaged between 1980 and 2010 as a measure of democratization. ${ }^{14}$ Polity scores take values between -10 and +10 . Negative scores are for autocracies and the more negative the score the more autocratic the regime. Positive scores are for democracies and a score of +10 goes to fully institutionalized democracies. Note that many countries have a score of +10 . Taking an average over 30 years is useful because many countries switched from autocracy to democracy during that period and the average score reflects the time since democracy was established as well as the quality of democracy. This period covers many democratization episodes that took place during the socalled third wave of democratization (Huntington 1991) but it does not cover yet the results of the Arab Spring. Although Polity IV data go back much further in time, we focus on the more recent period because our cultural data were generated starting from the 1970s. The geographical distribution of polity scores is shown in Panel A of Fig. 2.

To measure individualism/collectivism, we use the country level data developed by Hofstede (2001) who initially used surveys of IBM employees in about 30 countries in the 1960s. To avoid cultural biases in the way questions were framed, the survey was translated into local languages by a team of English and local language speakers. With new waves of surveys and replication studies, Hofstede's measure of individualism has been expanded to more than 90 countries. ${ }^{15}$ The individualism score measures the extent to which it is believed that individuals are supposed to take care of themselves as opposed to being strongly integrated and loyal to a cohesive group. Individuals in countries with a high level of the individualism index value personal freedom and status, while individuals in countries with a low level of the index value harmony and conformity. Hofstede's index, as well as the measures of individualism from other studies, uses a broad array of survey questions to establish cultural values. Factor analysis is used to summarize data and

\footnotetext{
14 Polity $\mathrm{V}$ is still in development as we write this paper.

15 The most current version of the data is available at http://www.geert-hofstede.com/. The timing of this and other variables is provided in "Appendix Table 9".
} 
construct indices. In Hofstede's analysis, the index of individualism is the first factor in work goal questions about the value of personal time, freedom, interesting and fulfilling work, etc. This component loads positively on valuing individual freedom, opportunity, achievement, advancement, recognition and negatively on valuing harmony, cooperation, relations with superiors. Although Hofstede's data were initially collected mostly with the purpose of understanding differences in IBM's corporate culture, the main advantage of Hofstede's measure of individualism is that it has been validated in a large number of studies. The ranking of countries across various studies and measures (see Hofstede (2001) for a review) is very stable. Hofstede's measure has been used extensively in the cross-cultural psychology literature, which views the individualism-collectivism cleavage as the main cultural cleavage across countries (see Heine 2008). The Hofstede data also correlate quite well with the more recent data by Schwartz $(1994,2006) .{ }^{16}$ Panel B of Fig. 2 shows the geographic distribution of individualism scores.

Empirically, the causality between individualism and democracy can go both ways. One can argue, as we do in this paper, that individualistic culture has a positive effect on democracy, but one can also make an argument in the other direction: the more people live under democracy and are accustomed to the protection of the rights of individual citizens, the more they espouse an individualistic world view with its values of freedom and opportunity, equality of citizens before the law and constraints on the executive (see for example Persson and Tabellini 2009). As we showed above, this does not change the results of the model, but would affect the empirical analysis. Ideally, we would like to have a measure of individualism and collectivism much earlier in time, prior to democratization history. Unfortunately, we do not have such data. We are therefore forced, in an attempt to deal with the potential endogeneity of culture, to use instrumental variables.

Our main instrumental variable is based on epidemiological data put together by Murray and Schaller (2010) for 230 geopolitical regions (mostly nations) on historical pathogen prevalence in the early-to-mid twentieth century, extending the work of Fincher et al. (2008). ${ }^{17}$ These historical data are very important because they give a good idea of the pathogen environment populations were facing in the past, including the very distant past, and in any case before the post-WWII epidemiological revolution when big public health changes started to occur. Panel C of Fig. 2 shows the geographical distribution of historic pathogen prevalence. Given a strong correlation between pathogen prevalence and collectivism, the above studies argue that stronger pathogen prevalence pushed communities to adopt more collectivist values emphasizing tradition, putting stronger limits on individual behavior, and showing less openness towards foreigners. Collectivism is thus understood as a defense mechanism created to cope with greater pathogen prevalence. Obviously, historical pathogen prevalence is only one of the possible reasons for the adoption of collectivism. Nevertheless, as an instrumental variable, it can provide a very useful role in measuring the effect of individualism on democratization. Historical pathogen prevalence can also be argued to satisfy the exclusion restriction since historical pathogen prevalence is not likely to have a direct effect on political regime choice. Indeed, one cannot claim that autocracy is more efficient than democracy, or vice versa, in dealing with pathogen

\footnotetext{
16 Schwartz's cultural dimensions of intellectual and affective autonomy correlate positively with individualism while the dimension of embeddedness correlates negatively with individualism. These cultural dimensions are also interpreted in a very similar way as Hofstede's individualism-collectivism index.

17 The study use 9 pathogens: leishmanias, trypanosomes, malaria, schistosomes, filariae, dengue, typhus, leprosy and tuberculosis.
} 
Panel A: Polity score (Source: http://www.systemicpeace.org/polity/polity4.htm)

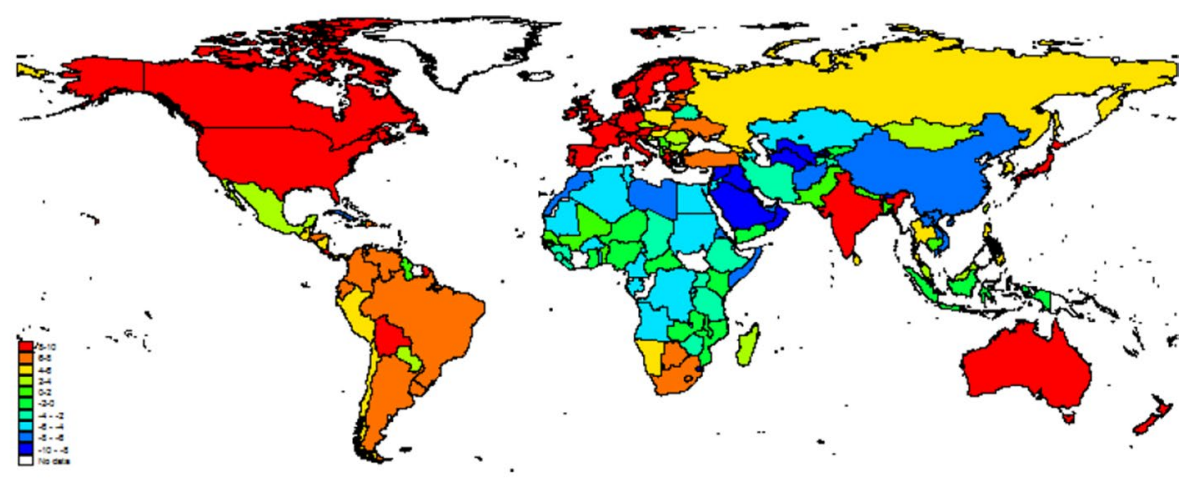

Panel B: Individualism (Source: http://geert-hofstede.com/)

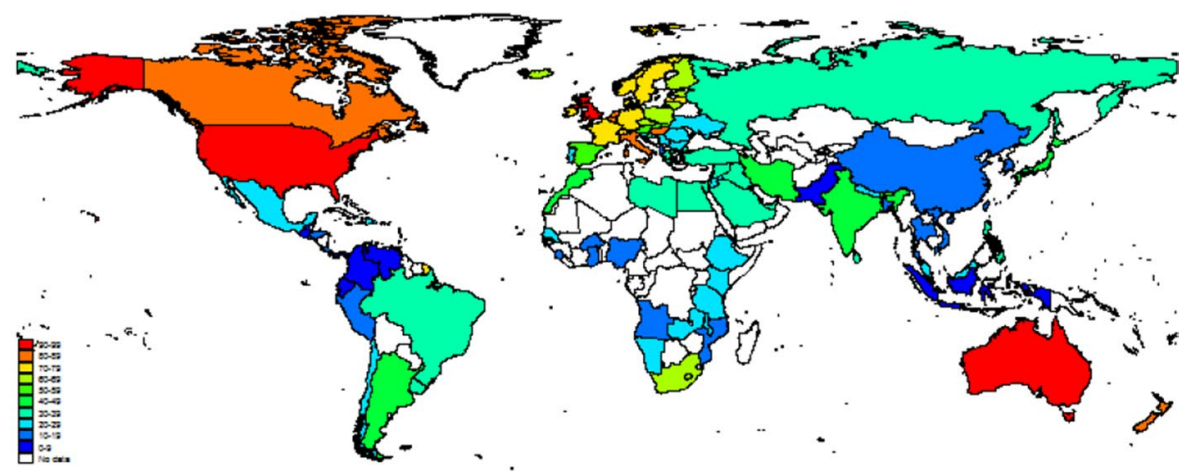

Panel C: Pathogen prevalence (Source: Murray and Schaller 2010)

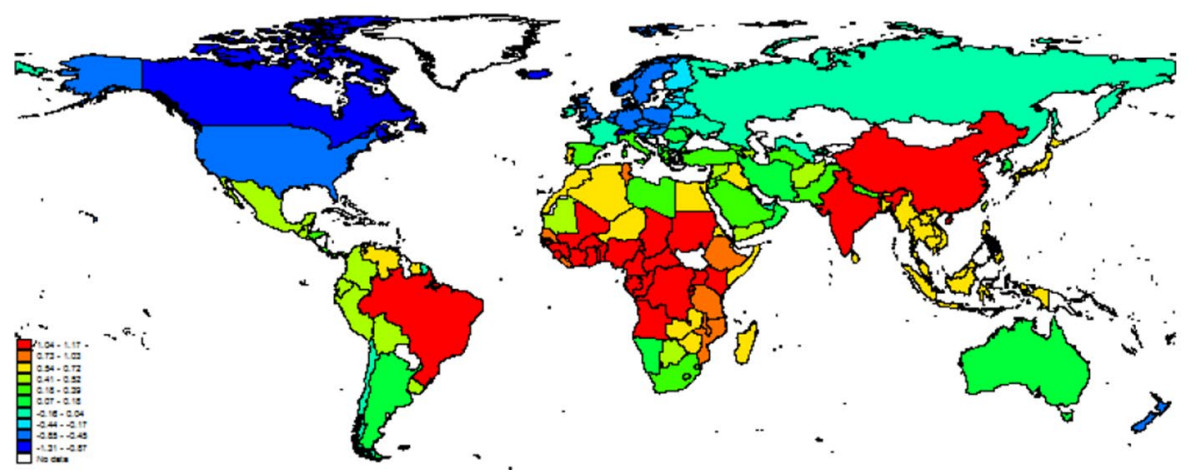

Fig. 2 Geographical distribution of individualism, polity scores, and pathogen prevalence

prevalence. Autocracy suffers from lack of transparency, as was seen in China recently with the SARS and COVID-19 epidemic, and is not necessarily more efficient in dealing with a humanitarian disaster, as was the case with the catastrophic handling of the 2008 
massive flooding from cyclone Nargis in Myanmar. Likewise, democracy may or may not lack speed in response to a major health epidemic. ${ }^{18}$

In some specifications we use another instrumental variable in conjunction with historical pathogen prevalence: the Euclidian distance between the frequency of blood types A and $\mathrm{B}$ in a given country and the frequency of those blood types in the USA, which is the most individualistic country in our sample. This is a measure of genetic distance. To the extent that culture is transmitted mainly from parents to children (see for example Fernandez et al. 2004; Fernandez and Fogli 2006, and the models by Bisin and Verdier 2000, 2001), so are genes. Populations that interbreed a lot should be genetically and culturally close because a similar parental transmission mechanism is at work in both cases. Therefore, measures of genetic distance can be seen as a proxy measure of differences in cultural values. Note that these are "neutral" genetic markers that have no direct effect on fitness (i.e., ability to think, run, work, etc.) and thus economic, cultural or political outcomes. Because genetic pools evolve slowly, these markers are very unlikely to be affected by economic outcomes, and thus we can exclude reverse causality in our instrumental variable estimates. To be clear, this particular identification strategy does not postulate that the first stage captures a direct causal effect between genes (here blood types) and culture. Instead, this strategy exploits the correlation between cultural and genetic transmission from patents to offspring. We combine this variable with the other instrumental variable mentioned above and apply standard statistical tests for the exclusion restriction. Our measure of genetic distance successfully passes these tests, and one can thus feel more comfortable using it as instrumental variable. ${ }^{19}$

The genetic data originate from Cavalli-Sforza et al. (1994), which provides measured genetic markers for roughly 2000 groups of population across the globe. These data contain allele frequencies (alleles are variants taken by a gene) for various ethnic groups. Using the frequency of blood types is attractive because, apart from being neutral genetic markers, the frequency of alleles determining blood types is the most widely available genetic information and thus we can construct the most comprehensive (in terms of country coverage) measure of genetic distance. Since the genetic data are available at the level of ethnic groups while our analysis is done at the country level, we have aggregated genetic information using ethnic shares of population from Fearon (2003). Gorodnichenko and Roland (2017) provide more details on how genetic distance is constructed. ${ }^{20}$

\subsection{Individualism and democracy in cross-section}

We now present the empirical results of the effects of individualism on average polity scores. The first three columns of Table 1 report results for the basic OLS and IV regressions. The effect of individualism is strongly significant with OLS and with IV, whether we

\footnotetext{
18 One could argue that higher pathogen prevalence should be correlated with a more centralized form of government given the externalities from disease transmission. However, centralization of government is not directly related to the type of political regime.

19 Using a smaller sample of countries, Gorodnichenko and Roland (2017) test overidentifying restrictions for the blood distance and other genetic instrumental variables with arguably more direct effects on individualism and collectivism and find that one cannot reject the null of correct exclusion restrictions.

20 A potential disadvantage of blood type distance as an instrumental variable is that it could be an instrument for other cultural variables, which may also be argued to affect political regime choice. Having two plausible instruments is nevertheless an advantage in empirical analysis because one can use formal tests of the exclusion restriction.
} 
take only historical pathogen prevalence as an instrument, or together with blood distance. Note that in the two IV regressions, the first stage is very significant, indicating no problem of weak instrument. Moreover, the $p$ value of 0.856 for the overidentifying restriction test confirms that one cannot reject the null of the instrumental variables being correctly excluded at any standard significance level. Note that the IV coefficients are somewhat higher than the OLS coefficient, indicating a potential measurement error. If we take the IV coefficient in column 3 as a baseline indicator, it means that a one standard deviation increase in individualism (say from Iran to Finland, or Argentina to Switzerland) should lead to a 4 point increase in the average polity score.

In columns 4 to 6 , we perform the same regressions but include controls for conflict. Countries plagued by conflict may indeed be more likely to have democracy suspended or eliminated during periods of conflict. We thus include four variables from the International Country Risk Guide, averaged between 1985 and 2009. These variables measure perceptions of risk for (1) cross-border conflict, (2) civil disorder, (3) ethnic tensions and (4) war. Even with more controls, the IV first stages are strong and the $p$-value for the overidentifying restriction is far above conventional significance levels. Note that the inclusion of controls for conflict tends to increase the size of the coefficient for individualism. We will include these four controls in the rest of our empirical specification to control for these potentially confounding factors.

One may be concerned that, perhaps, controlling for other cultural dimensions can eliminate statistical and economic significance of the individualism-democracy relationship. For example, Hofstede identified four other cultural dimensions: power distance, masculinity, uncertainty avoidance and long-term orientation. ${ }^{21}$ Fish (2002) found a negative correlation between democracy and Islam. Inglehart (1999) argues that interpersonal trust is conducive to stable democracies. In Table 2, we assess whether including these cultural characteristics alters the strength of the individualism-democracy link. Specifically, we control for the four additional Hofstede indexes, the share of Muslim population in 1970 [these data are from Barro and McCleary (2003)], and generalized trust (taken from the World Values Survey (WVS); an average value across available waves of the WVS). The share of Muslim population has a significantly negative coefficient, which is consistent across specifications. ${ }^{22}$ The only other cultural characteristic with similar consistency across specifications is uncertainty avoidance. Interestingly, although trust, the cultural variable the most used by economists, is positively correlated with Polity IV scores, this correlation disappears once we control for individualism scores. The magnitude of the coefficient on individualism is largely unchanged across specification.

In Table 3, we focus on four key economic factors typically linked to the prevalence of democracy: income, institutions, inequality, and natural resource rents. As highlighted in

\footnotetext{
21 Power distance measures the extent to which the less powerful members of organizations and institutions (like the family) accept and expect that power is distributed unequally. Uncertainty avoidance measures a society's tolerance for ambiguity. Masculinity measures a preference in society for achievement, heroism, assertiveness and material rewards for success. Cultures with high long-term orientation scores are characterized by emphasis on persistence (perseverance), ordering relationships by status, the possibility of having many truths (depending on time and context), thrift, and having a sense of shame.

22 When introducing shares of other religions (results not shown), the share of Muslims remains strongly negatively significant and is the only strongly robust variable. The share of Jews is typically positively associated to democracy. Given that Jews are a minority in all countries except Israel, the most natural interpretation is that Jews, who have been persecuted in the past, have migrated to the more stable democratic countries in the world.
} 
Table 1 Individualism and democratization

\begin{tabular}{|c|c|c|c|c|c|c|}
\hline $\begin{array}{l}\text { Dependent variable: } \\
\text { polity score }\end{array}$ & (1) & (2) & $\begin{array}{l}\text { IV blood dis- } \\
\text { tance + patho- } \\
\text { gens } \\
\text { (3) }\end{array}$ & (4) & (5) & $\begin{array}{l}\text { IV blood dis- } \\
\text { tance + path- } \\
\text { ogens } \\
\text { (6) }\end{array}$ \\
\hline Individualism & $\begin{array}{l}0.130^{* * * *} \\
(0.018)\end{array}$ & $\begin{array}{l}0.201 * * * \\
(0.028)\end{array}$ & $\begin{array}{l}0.199 * * * \\
(0.026)\end{array}$ & $\begin{array}{l}0.160^{* * * *} \\
(0.025)\end{array}$ & $\begin{array}{l}0.278 * * * \\
(0.055)\end{array}$ & $\begin{array}{l}0.250 * * * \\
(0.042)\end{array}$ \\
\hline \multicolumn{7}{|l|}{ Low risk of: } \\
\hline $\begin{array}{l}\text { Cross-border } \\
\text { conflict }\end{array}$ & & & & $\begin{array}{l}0.137 \\
(1.408)\end{array}$ & $\begin{array}{l}-0.218 \\
(1.422)\end{array}$ & $\begin{array}{l}-0.132 \\
(1.403)\end{array}$ \\
\hline Civil disorder & & & & $\begin{array}{l}-2.152^{*} \\
(1.116)\end{array}$ & $\begin{array}{l}-4.443 * * * \\
(1.573)\end{array}$ & $\begin{array}{l}-3.884 * * * \\
(1.320)\end{array}$ \\
\hline Ethnic tensions & & & & $\begin{array}{l}0.944 * * \\
(0.426)\end{array}$ & $\begin{array}{l}0.855^{*} \\
(0.479)\end{array}$ & $\begin{array}{l}0.877^{*} \\
(0.456)\end{array}$ \\
\hline War & & & & $\begin{array}{l}1.670 \\
(1.907)\end{array}$ & $\begin{array}{l}2.845 \\
(1.877)\end{array}$ & $\begin{array}{l}2.559 \\
(1.854)\end{array}$ \\
\hline Observations & 96 & 96 & 96 & 92 & 92 & 92 \\
\hline $\mathrm{R}^{2}$ & 0.236 & 0.166 & 0.170 & 0.334 & 0.196 & 0.255 \\
\hline 1st stage F-stat & & 95.73 & 51.18 & & 42.19 & 28.81 \\
\hline 1st stage Partial $\mathrm{R}^{2}$ & & 0.445 & 0.515 & & 0.277 & 0.392 \\
\hline Overid test $p$-value & & & 0.856 & & & 0.319 \\
\hline
\end{tabular}

Basic OLS and IV regressions

The dependent variable is the average polity score for the 1980-2010 period from the Polity IV data base. Individualism is Hofstede's index of individualism. A larger value of the index corresponds to a greater level of individualism. The four conflict variables (low risk of: cross-border conflict, civil disorder, ethnic tensions and war) are taken from the International Country Risk Guide and are averaged between 1985 and 2009. A higher score means a lower risk of the variable. Instrumental variables for individualism: historical pathogens is the Historical Pathogen prevalence index from Murray and Schaller (2010); blood distance is the Euclidian distance of frequency of blood types A and B in a given country relative to their frequency in the USA. Over-id test $p$-value reports the $p$-value for the overidentifying restriction tests that instruments are correctly excluded. Robust standard errors in parentheses. $* * * p<0.01, * * p<0.05, * p<0.1$

the introduction, since Lipset (1959), discussions on the determinants of democracy have turned around measures of economic development. We use the log of income (at purchasing power parity) per worker in 2000 from the Penn World Tables as a control for the level of economic development to maximize the coverage of countries.

Acemoglu and Robinson (2006) and others argue that extractive/non-inclusive institutions create barriers for transitions to democracy. ${ }^{23}$ To quantify the quality of institutions, we follow Acemoglu et al. (2001) and measure the quality of institutions as the score for protection against expropriation rights from the ICRG averaged over the 1985-2009 period.

23 Acemoglu et al. (2008) claim that income has no effect on democracy and that the comovement between these two variables is determined by institutions (the rule of law) that affect both democracy and successful economic development. 


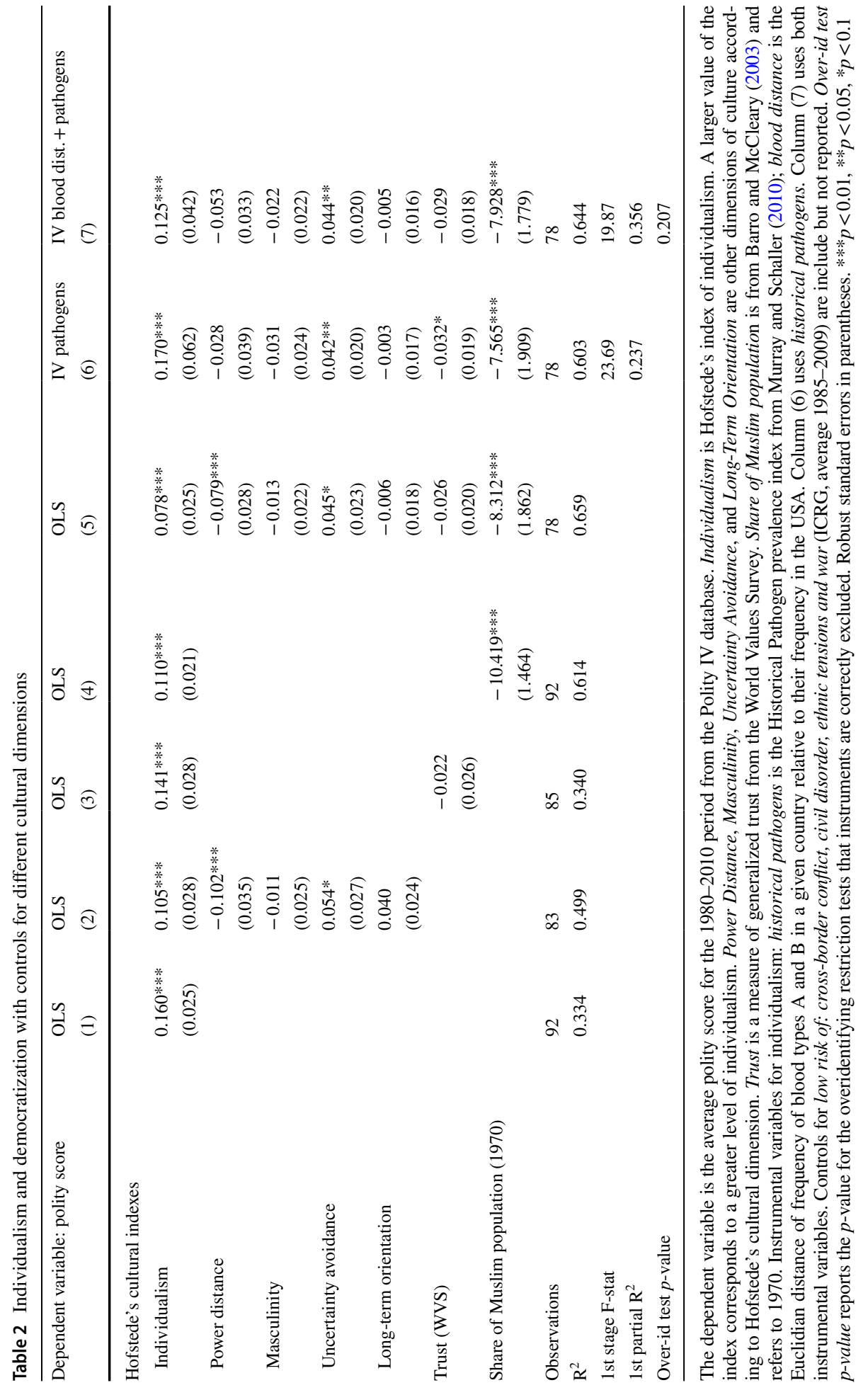


Table 3 Individualism and democratization with controls for income, institutions, rents and inequality

\begin{tabular}{|c|c|c|c|c|c|}
\hline Dependent variable: polity score & (1) & (2) & (3) & (4) & $(5)$ \\
\hline \multicolumn{6}{|l|}{ Panel A: OLS } \\
\hline Individualism & $\begin{array}{l}0.123^{* * *} \\
(0.035)\end{array}$ & $\begin{array}{l}0.148 * * * \\
(0.027)\end{array}$ & $\begin{array}{l}0.120 * * * \\
(0.027)\end{array}$ & $\begin{array}{l}0.122 * * * \\
(0.023)\end{array}$ & $\begin{array}{c}0.048 * \\
(0.027)\end{array}$ \\
\hline Log income per worker & $\begin{array}{l}2.332 * * * \\
(0.771)\end{array}$ & & & & $\begin{array}{l}3.479 * * * \\
(0.701)\end{array}$ \\
\hline Protection against expropriation risk & & $\begin{array}{l}0.309 * * \\
(0.133)\end{array}$ & & & $\begin{array}{c}0.009 \\
(0.133)\end{array}$ \\
\hline Natural resource rent & & & $\begin{array}{c}-0.233 * * * \\
(0.047)\end{array}$ & & $\begin{array}{c}-0.151 * * \\
(0.057)\end{array}$ \\
\hline Gini coefficient & & & & $\begin{array}{c}0.002 \\
(0.047)\end{array}$ & $\begin{array}{c}0.057 \\
(0.039)\end{array}$ \\
\hline $\mathrm{R}^{2}$ & 0.423 & 0.374 & 0.498 & 0.350 & 0.612 \\
\hline \multicolumn{6}{|l|}{ Panel B: IV (historic pathogen prevalence) } \\
\hline Individualism & $\begin{array}{l}0.223^{* * *} \\
(0.071)\end{array}$ & $\begin{array}{l}0.258 * * * \\
(0.056)\end{array}$ & $\begin{array}{l}0.251 * * * \\
(0.062)\end{array}$ & $\begin{array}{l}0.275^{* * *} \\
(0.064)\end{array}$ & $\begin{array}{l}0.182 * * \\
(0.080)\end{array}$ \\
\hline Log income per worker & $\begin{array}{c}1.427 \\
(0.896)\end{array}$ & & & & $\begin{array}{l}2.103^{* *} \\
(0.954)\end{array}$ \\
\hline Protection against expropriation risk & & $\begin{array}{c}0.213 \\
(0.145)\end{array}$ & & & $\begin{array}{c}0.031 \\
(0.140)\end{array}$ \\
\hline Natural resource rent & & & $\begin{array}{c}-0.161 * * * \\
(0.062)\end{array}$ & & $\begin{array}{c}-0.119^{*} \\
(0.064)\end{array}$ \\
\hline Gini coefficient & & & & $\begin{array}{c}0.081 \\
(0.066)\end{array}$ & $\begin{array}{l}0.100 * \\
(0.059)\end{array}$ \\
\hline $\mathrm{R}^{2}$ & 0.342 & 0.260 & 0.349 & 0.086 & 0.458 \\
\hline 1st stage F-stat & 17.37 & 34.72 & 35.76 & 26.41 & 9.473 \\
\hline 1st stage Partial $\mathrm{R}^{2}$ & 0.164 & 0.255 & 0.248 & 0.232 & 0.106 \\
\hline \multicolumn{6}{|c|}{ Panel C: IV (historic pathogen prevalence + blood distance) } \\
\hline Individualism & $\begin{array}{l}0.205^{* * *} \\
(0.052)\end{array}$ & $\begin{array}{l}0.244 * * * \\
(0.040)\end{array}$ & $\begin{array}{l}0.224 * * * \\
(0.045)\end{array}$ & $\begin{array}{l}0.224 * * * \\
(0.045)\end{array}$ & $\begin{array}{l}0.133 * * \\
(0.053)\end{array}$ \\
\hline Log income per worker & $\begin{array}{l}1.586^{* *} \\
(0.795)\end{array}$ & & & & $\begin{array}{l}2.602 * * * \\
(0.874)\end{array}$ \\
\hline Protection against expropriation risk & & $\begin{array}{c}0.225^{*} \\
(0.134)\end{array}$ & & & $\begin{array}{c}0.023 \\
(0.132)\end{array}$ \\
\hline Natural resource rent & & & $\begin{array}{c}-0.176^{* * *} \\
(0.055)\end{array}$ & & $\begin{array}{c}-0.131 * * \\
(0.057)\end{array}$ \\
\hline Gini coefficient & & & & $\begin{array}{c}0.055 \\
(0.056)\end{array}$ & $\begin{array}{c}0.085^{*} \\
(0.049)\end{array}$ \\
\hline $\mathrm{R}^{2}$ & 0.368 & 0.287 & 0.404 & 0.233 & 0.549 \\
\hline 1st stage F-stat & 14.79 & 27.34 & 25.23 & 20.29 & 11.51 \\
\hline 1st stage Partial $\mathrm{R}^{2}$ & 0.290 & 0.398 & 0.358 & 0.344 & 0.244 \\
\hline Overid test $p$-value & 0.693 & 0.686 & 0.401 & 0.146 & 0.425 \\
\hline Observations & 91 & 92 & 91 & 87 & 86 \\
\hline
\end{tabular}

The dependent variable is the average polity score for the 1980-2010 period from the Polity IV data base. Individualism is Hofstede's index of individualism. A larger value of the index corresponds to a greater 
Table 3 (continued)

level of individualism. Log income per worker: log income (at purchasing power parity) per worker in 2000 from the Penn World Tables. Protection against expropriation risk (ICRG, average 1985-2009). Gini coefficient of net income inequality is from the Standardized World Income Inequality Data base. Natural resource rent is the sum of oil rents, natural gas rents, coal rents (hard and soft), mineral rents, and forest rents. This variable is measured in percent of GDP (average over 1980-2010) and taken from the World Development Indicators. Controls low risk of: cross-border conflict, civil disorder, ethnic tensions and war (ICRG, average 1985-2009) are included but not reported. Instrumental variables for individualism: historical pathogens is the Historical Pathogen prevalence index from Murray and Schaller (2010); blood distance is the Euclidian distance of frequency of blood types A and B in a given country relative to their frequency in the USA. Over-id test $p$-value reports the $p$-value for the overidentifying restriction tests that instruments are correctly excluded. Robust standard errors in parentheses. $* * * p<0.01, * * p<0.05, * p<0.1$

Inequality has also been argued to be related to democratization. It is a key variable in the Acemoglu-Robinson model of democratization. A higher level of inequality makes democracy more advantageous, as it will lead to higher levels of redistribution. On the other hand, very high levels of inequality may lead the elite to stage coups to eliminate the associated tax burden. We measure inequality with the Gini coefficient for net income. This variable is taken from the Standardized World Income Inequality Database. To minimize measurement errors and short-term volatility in the series, we take a median value of the inequality over the 1960-2009 period.

Finally, we employ a measure of natural resource rents. Ross (2001), Wantchekon (2002), Dunning (2008) and others provide evidence suggesting that countries rich in natural resources may tend to be less democratic ("the political resource curse"). To account for this determinant, we use the share of natural resource rents in the gross domestic product. The share is averaged over 1980-2010 and taken from the World Development Indicators.

From an econometric point of view, these additional controls could be problematic in several respects. First, Gorodnichenko and Roland $(2011,2017)$ document a potential causal effect of individualism on income per capita and the quality of institutions. Hence, there could be an identification problem when both variables are used as regressors. Second, there might be reverse causality, i.e., democracy may affect the level of economic development, quality of institutions, level of inequality, and the extractive/non-extractive nature of the economy. Such endogeneity not only yields biased estimates of the coefficients on these economic variables but it is also likely to generate a downward bias in the estimate of the coefficient on individualism. ${ }^{24}$ As a result, the estimated coefficient on individualism scores likely provides a lower bound for the "true" coefficient. In short, one should exercise caution in interpreting regression coefficients in this specification, and also bear in mind that the estimated effect of individualism on democracy is likely to be understated.

We find that income is indeed positively correlated with Polity IV scores, but controlling for income or the other potential determinants does not appear to diminish the strength of the relationship between individualism and democracy. ${ }^{25}$ Note that income is not significant in the IV regressions, which could be because of the identification problem mentioned

\footnotetext{
${ }^{24}$ Gorodnichenko and Roland (2017) provide a more detailed discussion of this econometric problem.

25 Results are similar when we use consider measures of output for earlier periods. See "Appendix Table 10".
} 
above. In contrast, the share of natural resource rents in GDP is robustly negatively correlated with Polity IV scores. Inequality and the quality of institutions seem to have no robust association with democracy once we condition on other predictors. Importantly, results in Table 3 suggest that, even after controlling for economic factors emphasized in previous work, the effect of individualism is large and statistically significant.

In Table 4, we introduce controls for other variables that previous work has associated with democracy: education, measures of fractionalization and economic openness. Bourguignon and Verdier (2000), for example, build a model where education is both an engine of growth and of political participation. Column (1) includes the education index (average over 1980-2005) from the Human Development Report. We see that individualism and education are both statistically significant. In column (2), we introduce measures of ethnic, cultural and ethno-linguistic fractionalization from Fearon (2003). None of these variables comes out as significant, while individualism remains strongly significant. A similar result obtains in column (3) when we control for openness, measured as the ratio of exports plus imports to gross domestic product (in current prices, year 2000) and provided by Penn World Tables. The IV regressions in columns (4) through (6) yield similar results.

Conditional on the quality of our instrumental variables, we conclude that individualism has a significant and robust causal effect on the polity score, even after including controls that have been used in the literature, such as conflict, religion, income, institutions, education, fractionalization and openness.

\subsection{Long-difference analysis}

A potential drawback of cross-sectional analysis of democratization is that it does not exploit the time variation of the data. Fortunately, it is possible to perform panel data analysis of the polity score to understand the dynamics of democratization within a country. However, culture is slow-moving and it would be surprising to see important effects of culture on the basis of annual time variation. Furthermore, given that cultural attributes are likely to be measured with error, panel regressions based on annual data can exacerbate attenuation biases (see Griliches and Hausman 1986). Not surprisingly, analyses of cultural attributes almost invariably focus on cross-sectional variation.

In an attempt to strike a balance between a desired specification and data constraints, we report in Table 5 results based on "long-difference regressions" where the dependent variable is the difference in the polity index between 1960 and 2000 and regressors are the log difference of income per capita and the difference in the level of primary education during that same period as well as individualism and the polity score in 1960. This approach enhances the signal-to-noise ratio for the variables and one may thus obtain a crisper view of how variables are related. With long differences, individualism remains significant, except in columns (1) and (5), but this is mostly due to outliers. The coefficient on individualism is significant when we use Huber robust regressions.

\subsection{Years of democracy, collective action, collectivism and regime transitions}

We have so far used as dependent variable the average polity score between 1980 and 2010. An important advantage of this measure is that it incorporates the quality of democracy in a country as well as its length after 1980. In this subsection, we try to further explore dynamic aspects of the democratization process in the context of our model. In a first step, we examine the relationship between individualism and the frequency of democracy, which 
Table 4 Individualism and democratization with controls for fractionalization, education, and openness

\begin{tabular}{|c|c|c|c|c|c|c|}
\hline \multirow[t]{2}{*}{ Dependent variable: polity score } & \multicolumn{3}{|l|}{ OLS } & \multicolumn{3}{|l|}{ IV } \\
\hline & (1) & (2) & (3) & (4) & $(5)$ & (6) \\
\hline Individualism & $\begin{array}{l}0.104 * * * \\
(0.025)\end{array}$ & $\begin{array}{l}0.143 \text { *** } \\
(0.027)\end{array}$ & $\begin{array}{l}0.166^{* * *} \\
(0.027)\end{array}$ & $\begin{array}{l}0.130 * * \\
(0.055)\end{array}$ & $\begin{array}{l}0.214 * * * \\
(0.039)\end{array}$ & $\begin{array}{c}0.263 * * * \\
(0.046)\end{array}$ \\
\hline Ethnical fractionalization & & $\begin{array}{r}-5.078 \\
(4.272)\end{array}$ & & & $\begin{array}{r}-2.677 \\
(4.201)\end{array}$ & \\
\hline Cultural fractionalization & & $\begin{array}{r}-2.795 \\
(5.956)\end{array}$ & & & $\begin{array}{r}-2.182 \\
(5.444)\end{array}$ & \\
\hline Ethno-linguistic fractionalization & & $\begin{array}{c}0.896 \\
(4.072)\end{array}$ & & & $\begin{array}{r}-0.202 \\
(3.663)\end{array}$ & \\
\hline Education index & $\begin{array}{l}16.320 * * * \\
(3.485)\end{array}$ & & & $\begin{array}{l}15.027 * * * \\
(4.130)\end{array}$ & & \\
\hline Openness & & & $\begin{array}{c}0.012 \\
(0.011)\end{array}$ & & & $\begin{array}{c}0.019 * \\
(0.011)\end{array}$ \\
\hline Observations & 91 & 77 & 92 & 91 & 77 & 92 \\
\hline $\mathrm{R}^{2}$ & 0.494 & 0.382 & 0.342 & 0.489 & 0.336 & 0.252 \\
\hline 1st stage F-stat & & & & 17.05 & 45.67 & 26.95 \\
\hline 1st stage Partial $\mathrm{R}^{2}$ & & & & 0.250 & 0.550 & 0.377 \\
\hline Overid test $p$-value & & & & 0.632 & 0.324 & 0.492 \\
\hline
\end{tabular}

The dependent variable is the average polity score for the 1980-2010 period from the Polity IV data base. Individualism is Hofstede's index of individualism. A larger value of the index corresponds to a greater level of individualism. Ethnical, cultural and ethno-linguistical fractionalization are from Fearon (2003). Education: World Bank Human Development Report Education Index (average 1980-2005). Openness: Openness ratio in current prices (Penn World Tables). Controls for low risk of: cross-border conflict, civil disorder, ethnic tensions and war (ICRG, average 1985-2009) are included but not reported. Instrumental variables for individualism: historical pathogens is the Historical Pathogen prevalence index from Murray and Schaller (2010); blood distance is the Euclidian distance of frequency of blood types A and B in a given country relative to their frequency in the USA. Over-id test $p$-value reports the $p$-value for the overidentifying restriction tests that instruments are correctly excluded. Robust standard errors in parentheses. $* * * p<0.01, * * p<0.05, * p<0.1$

is defined as the fractions of years a country has continuously had a non-negative polity score. One may interpret this frequency as measuring the length of democracy in a country. While this measure does not take into account the quality of democracy, one can argue that this measure is closer to the model as the latter predicts that individualist cultures will on average adopt democracy earlier. We ran the same regressions as in Tables 1, 2, 3, 4 and 5 using length of democracy as the dependent variable and we reached essentially the same conclusions as before. In Table 6, we present some of the most salient results.

Column 1 presents the simple OLS regression of fraction of years in democracy on individualism. A one standard deviation in the individualism score leads to a 24 percentage point increase in the length of democracy. The instrumental variable regression in column 2, using historical pathogen prevalence and blood distance to the U.S. as instrumental variables predicts a 34 percentage point increase in response to a one standard deviation increase in the individualism score. The over-identification test clearly indicates that we cannot reject the null of the IVs being correctly excluded. Columns 3 and 4 control for log of income per worker, quality of institutions and the share of natural 


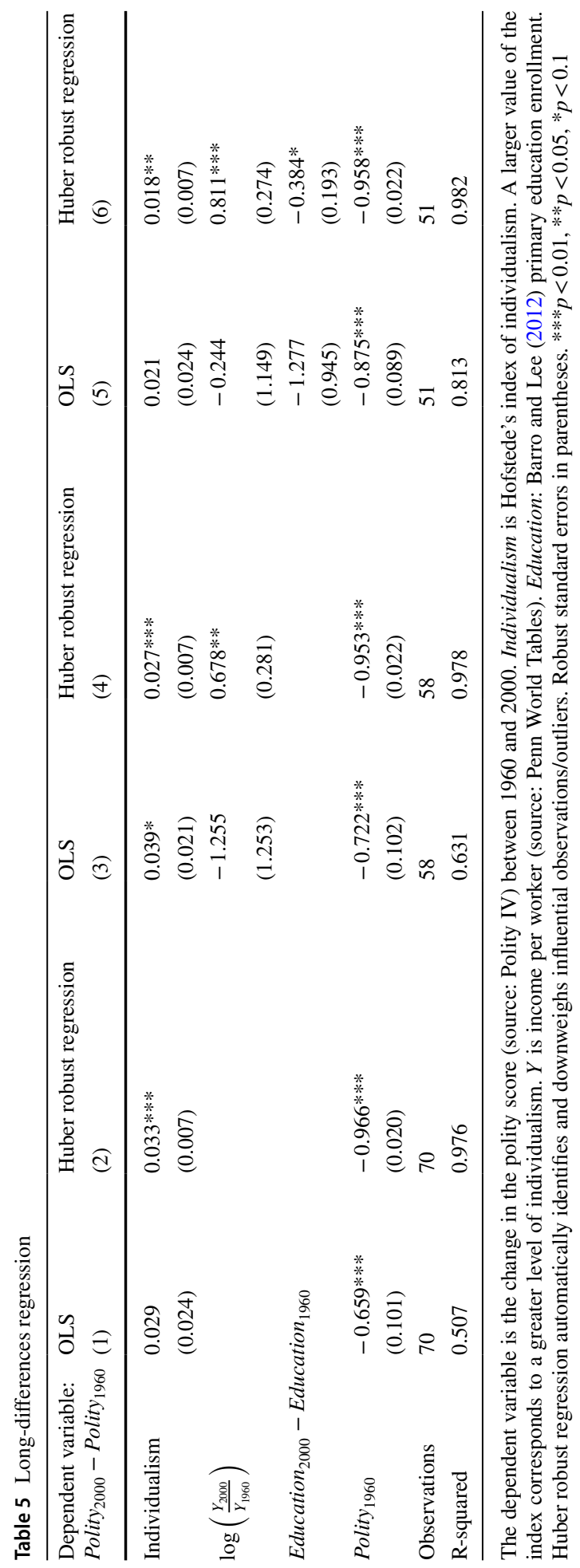


Table 6 Individualism and democratization

\begin{tabular}{|c|c|c|c|c|c|c|}
\hline $\begin{array}{l}\text { Dependent variable: fraction } \\
\text { of years with democracy }\end{array}$ & $\begin{array}{l}\text { OLS } \\
\text { (1) }\end{array}$ & $\begin{array}{l}\text { IV } \\
(2)\end{array}$ & $\begin{array}{l}\text { OLS } \\
\text { (3) }\end{array}$ & $\begin{array}{l}\text { IV } \\
(4)\end{array}$ & $\begin{array}{l}\text { OLS } \\
(5)\end{array}$ & $\begin{array}{l}\text { IV } \\
(6)\end{array}$ \\
\hline Individualism & $\begin{array}{l}1.128 * * * \\
(0.173)\end{array}$ & $\begin{array}{l}1.562 * * * \\
(0.270)\end{array}$ & $\begin{array}{l}0.734 * * * \\
(0.206)\end{array}$ & $\begin{array}{l}1.380 * * * \\
(0.386)\end{array}$ & $\begin{array}{l}0.674 * * * \\
(0.224)\end{array}$ & $\begin{array}{l}0.960 * * * \\
(0.300)\end{array}$ \\
\hline Log income per worker & & & $\begin{array}{l}8.273 * \\
(4.913)\end{array}$ & $\begin{array}{l}1.664 \\
(6.326)\end{array}$ & $\begin{array}{l}16.314 * * \\
(7.797)\end{array}$ & $\begin{array}{l}13.681 * \\
(7.262)\end{array}$ \\
\hline $\begin{array}{l}\text { Protection against expropria- } \\
\text { tion risk }\end{array}$ & & & $\begin{array}{l}2.141 * * \\
(1.001)\end{array}$ & $\begin{array}{l}2.376^{* *} \\
(1.059)\end{array}$ & $\begin{array}{l}1.276 \\
(1.120)\end{array}$ & $\begin{array}{l}1.482 \\
(1.063)\end{array}$ \\
\hline Natural resource rent & & & $\begin{array}{l}-0.837 * * * \\
(0.313)\end{array}$ & $\begin{array}{l}-0.487 \\
(0.393)\end{array}$ & $\begin{array}{l}-0.140 \\
(0.380)\end{array}$ & $\begin{array}{l}-0.042 \\
(0.361)\end{array}$ \\
\hline Education index & & & & & $\begin{array}{l}-53.955^{*} \\
(29.397)\end{array}$ & $\begin{array}{l}-63.253^{* *} \\
(25.968)\end{array}$ \\
\hline Ethnic fractionalization & & & & & $\begin{array}{l}8.155 \\
(25.278)\end{array}$ & $\begin{array}{l}12.232 \\
(24.146)\end{array}$ \\
\hline Cultural fractionalization & & & & & $\begin{array}{l}-14.509 \\
(36.542)\end{array}$ & $\begin{array}{l}-9.867 \\
(32.714)\end{array}$ \\
\hline $\begin{array}{l}\text { Ethno-linguistic fractionaliza- } \\
\text { tion }\end{array}$ & & & & & $\begin{array}{l}-8.628 \\
(23.211)\end{array}$ & $\begin{array}{l}-18.067 \\
(21.690)\end{array}$ \\
\hline Share of Muslim & & & & & $\begin{array}{l}-59.923 * * * \\
(12.643)\end{array}$ & $\begin{array}{l}-60.705^{* * *} \\
(11.421)\end{array}$ \\
\hline Observations & 92 & 92 & 91 & 91 & 77 & 77 \\
\hline $\mathrm{R}^{2}$ & 0.380 & 0.342 & 0.501 & 0.439 & 0.653 & 0.642 \\
\hline 1st stage F-stat & & 28.81 & & 14.05 & & 17.81 \\
\hline 1st stage Partial $\mathrm{R}^{2}$ & & 0.392 & & 0.273 & & 0.395 \\
\hline Overid test $p$-value & & 0.387 & & 0.814 & & 0.837 \\
\hline
\end{tabular}

Fraction of years with democracy

The dependent variable is the number of years since a country has established a democratic regime (the number of years with a continuous positive polity score from the Polity IV data base) as a fraction of the total number of years the country appears in the polity IV data base. Individualism is Hofstede's index of individualism. Log income per worker: log income (at purchasing power parity) per worker in 2000 from the Penn World Tables. Protection against expropriation risk (ICRG, average 1985-2009). Ethnical, cultural and ethno-linguistical fractionalization are from Fearon (2003). Education: World Bank Human Development Report Education Index (average 1980-2005). Natural resource rent is the sum of oil rents, natural gas rents, coal rents (hard and soft), mineral rents, and forest rents. This variable is measured in percent of GDP (average over 1980-2010) and taken from the World Development Indicators. Share of Muslim population is from Barro and McCleary (2003) and refers to 1970. Controls low risk of: cross-border conflict, civil disorder, ethnic tensions and war (ICRG, average 1985-2009) are included but not reported. Instrumental variables for individualism: historical pathogens is the Historical Pathogen prevalence index from Murray and Schaller (2010); blood distance is the Euclidian distance of frequency of blood types A and B in a given country relative to their frequency in the USA. Over-id test $p$-value reports the $p$-value for the overidentifying restriction tests that instruments are correctly excluded. Robust standard errors in parentheses. $* * * p<0.01, * * p<0.05, * p<0.1$

resource rents in gross domestic product. Although the point estimates on individualism scores are somewhat smaller, the effect continues to by economically and statistically significant. In columns 5 and 6 , we add controls for education, religion, conflict, and 


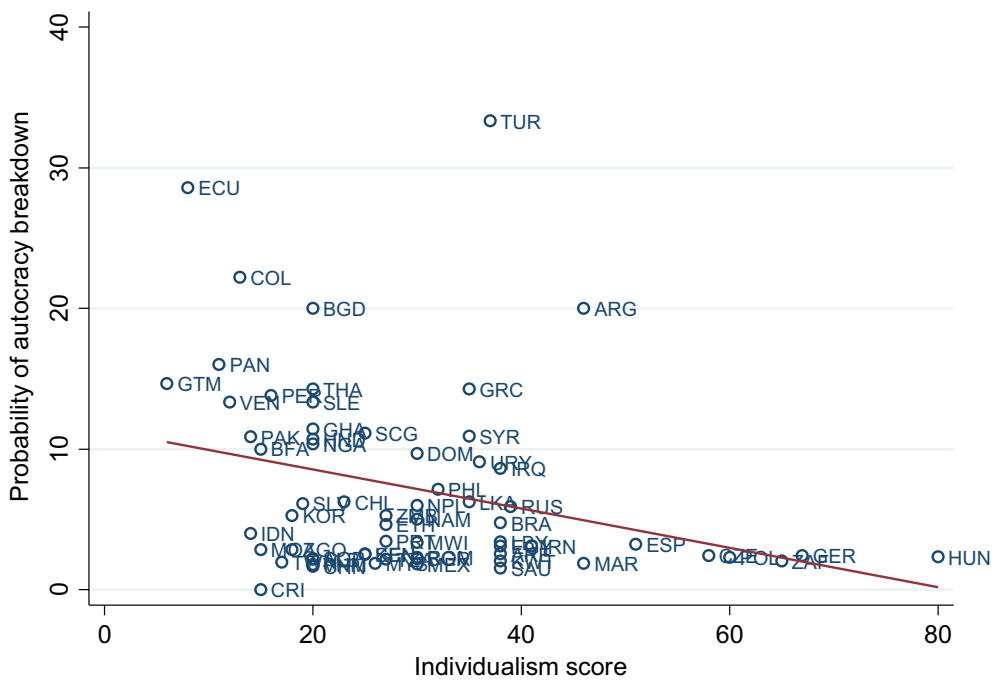

Fig. 3 Individualism and the probability of autocratic breakdown. Notes: Probability of autocracy breakdown is the fraction of years when a country has a change of autocrats conditional on starting as an autocracy. Source: Geddes et al. (2014)

measures of ethnic/cultural/linguistic fractionalization. In all these regressions individualism always has a significant effect on the length of democracy.

We did not make any assumptions in the model about whether collectivist cultures have a higher probability of successful collective action compared $\left(q_{C}\right)$ to individualist cultures $\left(q_{I}\right)$, and our main result did not hinge on this. It would nevertheless be useful to see if the data can give us some indication about whether there is more collective action under collectivism. In relation to this, we investigate whether collectivist autocracies have a higher likelihood of breakdown, be it through mass protests or coups, which would tend to suggest that there is more collective action success in more collectivist countries. In order to do this, we rely on the database assembled by Geddes et al. (2014). This database focuses on autocracies and, to our knowledge, is the best source documenting transitions from an autocratic regime to either democracy or another autocracy.

We define the probability of an autocracy breakdown as the number of autocracy breakdowns (coups, revolutions, elections, etc.) divided by the number of years a country has been under autocracy. This statistic from the Geddes et al. (2014) comes the closest to our parameter $q_{k}$. Figure 3 shows that there is a clear negative correlation between individualism and autocracy breakdown. In Table 7, we provide some regressions using autocracy breakdown as the dependent variable and the set of controls identical to those in Table 6. In all specifications the coefficient for individualism is negative, suggesting that among countries with an autocratic regime, those having a collectivist culture are more likely to experience autocracy breakdown. The coefficient is significant in all OLS regressions, but the IV coefficients are mostly not significant. The evidence presented here is weaker than in previous tables, but overall tends to suggest that there may be less collective action failure in collectivist cultures.

Importantly, the Geddes et al. (2014) database also makes it possible to analyze transitions from autocracy to autocracy and transitions from autocracy to democracy. The model clearly predicts that, in collectivist societies, there will be more transitions from bad autocracies to good autocracies because $\sigma_{C}>\sigma_{I}$ ). While it is difficult to distinguish empirically "bad" and 
Table 7 Probability of autocracy breakdown and individualism

\begin{tabular}{|c|c|c|c|c|c|c|}
\hline $\begin{array}{l}\text { Dependent variable: probability of } \\
\text { autocracy breakdown }\end{array}$ & $\begin{array}{l}\text { OLS } \\
\text { (1) }\end{array}$ & $\begin{array}{l}\text { IV } \\
(2)\end{array}$ & $\begin{array}{l}\text { OLS } \\
\text { (3) }\end{array}$ & $\begin{array}{l}\text { IV } \\
(4)\end{array}$ & $\begin{array}{l}\text { OLS } \\
(5)\end{array}$ & $\begin{array}{l}\text { IV } \\
(6)\end{array}$ \\
\hline Individualism & $\begin{array}{l}-0.068 \\
(0.047)\end{array}$ & $\begin{array}{l}0.026 \\
(0.070)\end{array}$ & $\begin{array}{l}-0.120^{* * *} \\
(0.048)\end{array}$ & $\begin{array}{l}-0.120 \\
(0.074)\end{array}$ & $\begin{array}{l}-0.141 * * \\
(0.056)\end{array}$ & $\begin{array}{l}-0.130^{*} \\
(0.071)\end{array}$ \\
\hline Log income per worker & & & $\begin{array}{l}2.847 * \\
(1.508)\end{array}$ & $\begin{array}{l}2.847 * \\
(1.624)\end{array}$ & $\begin{array}{l}3.101 * \\
(1.595)\end{array}$ & $\begin{array}{l}3.045 * * \\
(1.452)\end{array}$ \\
\hline Protection against expropriation risk & & & $\begin{array}{l}-0.435 \\
(0.291)\end{array}$ & $\begin{array}{l}-0.435 \\
(0.295)\end{array}$ & $\begin{array}{l}-0.555 \\
(0.350)\end{array}$ & $\begin{array}{l}-0.543^{*} \\
(0.308)\end{array}$ \\
\hline Natural resource rent & & & $\begin{array}{l}-0.069 \\
(0.057)\end{array}$ & $\begin{array}{l}-0.069 \\
(0.053)\end{array}$ & $\begin{array}{l}-0.114 \\
(0.093)\end{array}$ & $\begin{array}{l}-0.111 \\
(0.076)\end{array}$ \\
\hline Education index & & & & & $\begin{array}{l}4.114 \\
(8.799)\end{array}$ & $\begin{array}{l}3.751 \\
(7.477)\end{array}$ \\
\hline Ethnic fractionalization & & & & & $\begin{array}{l}3.843 \\
(4.527)\end{array}$ & $\begin{array}{l}3.925 \\
(3.965)\end{array}$ \\
\hline Cultural fractionalization & & & & & $\begin{array}{l}-1.205 \\
(6.280)\end{array}$ & $\begin{array}{l}-1.074 \\
(5.480)\end{array}$ \\
\hline Ethno-linguistic fractionalization & & & & & $\begin{array}{l}0.627 \\
(4.577)\end{array}$ & $\begin{array}{l}0.410 \\
(4.184)\end{array}$ \\
\hline Share of Muslim & & & & & $\begin{array}{l}1.436 \\
(4.059)\end{array}$ & $\begin{array}{l}1.293 \\
(3.427)\end{array}$ \\
\hline Observations & 63 & 63 & 62 & 62 & 55 & 55 \\
\hline $\mathrm{R}^{2}$ & 0.374 & 0.337 & 0.439 & 0.439 & 0.416 & 0.415 \\
\hline 1st stage F-stat & & 12.02 & & 10.70 & & 15.10 \\
\hline 1st stage Partial $\mathrm{R}^{2}$ & & 0.368 & & 0.283 & & 0.407 \\
\hline Overid test $p$-value & & 0.978 & & 0.713 & & 0.763 \\
\hline
\end{tabular}

The dependent variable is the probability of breakdown of autocracy for a country based on the dataset in Geddes et al. (2014). Individualism is Hofstede's index of individualism. Log income per worker: log income (at purchasing power parity) per worker in 2000 from the Penn World Tables. Protection against expropriation risk (ICRG, average 1985-2009). Ethnical, cultural and ethno-linguistical fractionalization are from Fearon (2003). Education: World Bank Human Development Report Education Index (average 1980-2005). Natural resource rent is the sum of oil rents, natural gas rents, coal rents (hard and soft), mineral rents, and forest rents. This variable is measured in percent of GDP (average over 1980-2010) and taken from the World Development Indicators. Share of Muslim population is from Barro and McCleary (2003) and refers to 1970. Controls low risk of: cross-border conflict, civil disorder, ethnic tensions and war (ICRG, average 1985-2009) are included but not reported. Instrumental variables for individualism: historical pathogens is the Historical Pathogen prevalence index from Murray and Schaller (2010); blood distance is the Euclidian distance of frequency of blood types A and B in a given country relative to their frequency in the USA. Over-id test $p$-value reports the $p$-value for the overidentifying restriction tests that instruments are correctly excluded. Robust standard errors in parentheses. $* * * p<0.01, * * p<0.05, * p<0.1$

"good" autocrats, we can examine the link between individualism and collectivism and the probability of regime changes. We define the probability of autocratic transition as the proportion of autocracy breakdowns leading to autocracy in a country. Because these variables are likely to very often take the value of 0 or 100 , we performed tobit regressions with censoring points at 0 and 100. The results are presented in Tables 8 , where we take the same controls as in Table 7 . We observe clearly that transitions from autocracy to autocracy are significantly negatively associated with individualism (and thus positively associated with collectivism) in 
Table 8 Individualism and transition from autocracy to autocracy (Tobit regressions)

\begin{tabular}{|c|c|c|c|c|c|c|}
\hline $\begin{array}{l}\text { Dependent variable: prob- } \\
\text { ability of transition from } \\
\text { autocracy to autocracy }\end{array}$ & $\begin{array}{l}\text { OLS } \\
(1)\end{array}$ & $\begin{array}{l}\text { IV } \\
(2)\end{array}$ & $\begin{array}{l}\text { OLS } \\
\text { (3) }\end{array}$ & $\begin{array}{l}\text { IV } \\
(4)\end{array}$ & $\begin{array}{l}\text { OLS } \\
(5)\end{array}$ & $\begin{array}{l}\text { IV } \\
(6)\end{array}$ \\
\hline Individualism & $\begin{array}{l}-5.941 * * * \\
(1.591)\end{array}$ & $\begin{array}{l}-7.978^{* * *} \\
(2.276)\end{array}$ & $\begin{array}{l}-3.830 * * * \\
(1.172)\end{array}$ & $\begin{array}{l}-5.738^{* * *} \\
(1.876)\end{array}$ & $\begin{array}{l}-3.807 * * * \\
(1.056)\end{array}$ & $\begin{array}{l}-3.837^{* *} \\
(1.618)\end{array}$ \\
\hline Log income per worker & & & $\begin{array}{l}-45.862 \\
(27.899)\end{array}$ & $\begin{array}{l}-21.929 \\
(32.396)\end{array}$ & $\begin{array}{l}2.704 \\
(35.761)\end{array}$ & $\begin{array}{l}3.147 \\
(37.574)\end{array}$ \\
\hline $\begin{array}{l}\text { Protection against expro- } \\
\text { priation risk }\end{array}$ & & & $\begin{array}{l}5.561 \\
(5.338)\end{array}$ & $\begin{array}{l}4.284 \\
(5.644)\end{array}$ & $\begin{array}{l}-0.706 \\
(5.398)\end{array}$ & $\begin{array}{l}-0.738 \\
(5.527)\end{array}$ \\
\hline Natural resource rent & & & $\begin{array}{l}6.118 * * * \\
(1.870)\end{array}$ & $\begin{array}{l}5.101 * * * \\
(1.750)\end{array}$ & $\begin{array}{l}4.270 * * * \\
(1.597)\end{array}$ & $\begin{array}{l}4.258 * * * \\
(1.531)\end{array}$ \\
\hline Education index & & & & & $\begin{array}{l}-121.069 \\
(126.738)\end{array}$ & $\begin{array}{l}-120.917 \\
(126.984)\end{array}$ \\
\hline Ethnic fractionalization & & & & & $\begin{array}{l}-66.145 \\
(84.370)\end{array}$ & $\begin{array}{l}-66.286 \\
(86.239)\end{array}$ \\
\hline Cultural fractionalization & & & & & $\begin{array}{l}70.798 \\
(118.219)\end{array}$ & $\begin{array}{l}70.052 \\
(123.922)\end{array}$ \\
\hline $\begin{array}{l}\text { Ethno-linguistic fraction- } \\
\text { alization }\end{array}$ & & & & & $\begin{array}{l}95.526 \\
(92.415)\end{array}$ & $\begin{array}{l}96.131 \\
(95.123)\end{array}$ \\
\hline Share of Muslim & & & & & $\begin{array}{l}123.272 * * \\
(58.435)\end{array}$ & $\begin{array}{l}123.113 * * \\
(58.653)\end{array}$ \\
\hline Observations & 84 & 84 & 83 & 83 & 72 & 72 \\
\hline
\end{tabular}

The dependent variable is the probability of transition from autocracy to autocracy for a country after an autocracy breakdown, based on the dataset in Geddes et al. (2014). Individualism is Hofstede's index of individualism. Log income per worker: log income (at purchasing power parity) per worker in 2000 from the Penn World Tables. Protection against expropriation risk (ICRG, average 1985-2009). Ethnical, cultural and ethno-linguistical fractionalization are from Fearon (2003). Education: World Bank Human Development Report Education Index (average 1980-2005). Natural resource rent is the sum of oil rents, natural gas rents, coal rents (hard and soft), mineral rents, and forest rents. This variable is measured in percent of GDP (average over 1980-2010) and taken from the World Development Indicators. Share of Muslim population is from Barro and McCleary (2003) and refers to 1970. Controls low risk of: cross-border conflict, civil disorder, ethnic tensions and war (ICRG, average 1985-2009) are included but not reported. Instrumental variables for individualism: historical pathogens is the Historical Pathogen prevalence index from Murray and Schaller (2010); blood distance is the Euclidian distance of frequency of blood types $\mathrm{A}$ and $\mathrm{B}$ in a given country relative to their frequency in the USA. Robust standard errors in parentheses. $* * * p<0.01, * * p<0.05, * p<0.1$

all specifications. Hence, both the polity data and the Geddes et al. (2014) data on autocracies and autocratic transitions give empirical support for these predictions of the model.

\section{Conclusions}

We have presented a model integrating culture in democratization processes. Assuming that a collectivist culture displays a stronger taste for conformity and a stronger aversion to institutional innovation even if it might be better at overcoming collective action 
problems, the model predicts that, starting from autocracy as the initial regime, an individualistic culture will have a higher likelihood of switching to democracy than a collectivist culture. The reason is that a collectivist culture will tend to stick to a "good" non-predatory autocracy, which will not be the case with an individualistic culture.

Predictions of the model have strong, robust support in the data, controlling for existing determinants identified in the literature. To the extent one believes our instrumental variable analysis, these effects may be interpreted as causal. Using long-difference regressions, we also find long-run effects of individualism on polity scores. Using the Geddes et al. (2014) data base on autocracies, we also found that collectivist autocracies have higher frequency of regime breakdowns than individualist autocracies. Consistent with the model, collectivist countries are more likely to experience a transition towards autocracy while individualist countries are more likely to experience a transition towards democracy.

Our theoretical and empirical results have important implications. In particular, as countries with collectivist cultures develop economically, they will not necessarily evolve towards democracy or might do so more slowly or possibly only under the effect of an exceptional crisis. This implication is in stark contrast with modernization theories. Countries like China, Vietnam or Singapore, which have experienced considerable economic success in recent decades have not adopted Western-style democracies. Similarly, countries that have experienced a genuine democratization process like Taiwan, Thailand, Indonesia and Korea have done so relatively recently and their average polity score over the last 30 years have not been better than Guatemala, Panama or Peru. Another implication of the model is that in the long run, we should observe only stable democracies and stable "good" autocracies. Testing such a prediction and analyzing factors affecting political stability is beyond the scope of this paper.

We must nevertheless be very cautious in interpreting these implications. There are many determinants of democracy and culture is only one of those forces. Our research nevertheless suggests that the role of culture, and in particular of individualism and collectivism as fundamental cultural dimension, cannot be ignored in understand democratization processes.

\section{Appendix}

Proof of Proposition 1 Under a good ruler, the poor prefer not to revolt if:

$$
V_{G N}=\frac{y^{P}}{1-\beta} \geq V_{G R}=y^{P}+\beta\left\{q_{k} \sigma_{k}\left[\alpha V_{G R}+(1-\alpha) V_{B}\right]+q_{k}\left(1-\sigma_{k}\right) V_{D}+\left(1-q_{k}\right) V_{G R}\right\}
$$

Using the expression for $V_{G R}-V_{B}=y^{P}+\beta\left(1-q_{k}\right)\left(V_{G R}-V_{B}\right)=\frac{y^{P}}{1-\beta\left(1-q_{k}\right)}$ we get

$$
\begin{aligned}
& V_{G N} \geq V_{G R} \\
& \Leftrightarrow \frac{y^{P}}{1-\beta} \geq y^{P}+\beta\left\{q_{k} \sigma_{k} \alpha \frac{y^{P}}{1-\beta\left(1-q_{k}\right)}+q_{k} \sigma_{k}\left(V_{G R}-\frac{y^{P}}{1-\beta\left(1-q_{k}\right)}\right)+q_{k}\left(1-\sigma_{k}\right) V_{D}+\left(1-q_{k}\right) V_{G R}\right\} \\
& \Leftrightarrow \frac{y^{P}}{1-\beta} \geq y^{P}+\beta\left\{q_{k}\left(1-\sigma_{k}\right) V_{D}-(1-\alpha) q_{k} \sigma_{k} \frac{y^{P}}{1-\beta\left(1-q_{k}\right)}+\left(1-q_{k}\left(1-\sigma_{k}\right)\right) V_{G R}\right\}
\end{aligned}
$$

Since the right hand side of the inequality is equal to $V_{G R}$, we have that 


$$
\begin{aligned}
& V_{G N} \geq V_{G R} \\
& \Leftrightarrow \frac{y^{P}}{1-\beta} \geq \frac{1}{1-\beta\left(1-q_{k}\left(1-\sigma_{k}\right)\right)}\left\{y^{P}+\beta\left[q_{k}\left(1-\sigma_{k}\right) V_{D}-(1-\alpha) q_{k} \sigma_{k} \frac{y^{P}}{1-\beta\left(1-q_{k}\right)}\right]\right\}
\end{aligned}
$$

A quick look at this last inequality shows several things. First, a high degree of conformity (a high $\sigma_{k}$ ) implies the preference not to revolt. With $\sigma_{k} \rightarrow 1$,

$$
V_{G R} \rightarrow \frac{1}{1-\beta}\left\{y^{P}-\beta(1-\alpha) q_{k} \frac{y^{P}}{1-\beta\left(1-q_{k}\right)}\right\}<\frac{y^{P}}{1-\beta}
$$

Note now that when $\sigma_{k}$ is low and tends towards zero, there will be a strict preference to revolt. Indeed, in that case:

$$
V_{G R} \rightarrow \frac{1}{1-\beta\left(1-q_{k}\right)}\left\{y^{P}+\beta q_{k} V_{D}\right\} \geq \frac{y^{P}}{1-\beta}=V_{G N} \Leftrightarrow V_{D} \geq V_{G N}
$$

The latter inequality is always satisfied as democracy brings positive redistribution to the poor. Since $V_{G N}>V_{G R}$ for high values of $\sigma_{k}$ and $V_{G N}<V_{G R}$ for low values of $\sigma_{k}$ and since $\frac{\partial V_{G R}}{\partial \sigma_{k}}<0$, by continuity, there exists a threshold value $\bar{\sigma}_{k}$, at which the poor are indifferent between revolting and not revolting. Above $\bar{\sigma}_{k}$, they prefer not to revolt against a good autocrat, and below $\bar{\sigma}_{k}$ they prefer to revolt against a good autocrat.

Proof of Proposition 2 Under a collectivist culture with a high enough $\sigma_{k}$ above $\bar{\sigma}_{k}$ such that the poor decide not to revolt, the probability of ending up with a democratic regime after $t$ periods can be shown to be equal to

$$
(1-\alpha) q_{k}\left(1-\sigma_{k}\right) \sum_{j=0}^{t}\left\{q_{k} \sigma_{k}(1-\alpha)\right\}^{j}
$$

When $t \rightarrow \infty$, the probability of having democracy converges to

$$
\frac{(1-\alpha) q_{k}\left(1-\sigma_{k}\right)}{1-(1-\alpha) q_{k} \sigma_{k}}
$$

Note that this expression tends towards zero as $\sigma_{k} \rightarrow 1$.Under an individualist culture with a low enough $\sigma_{k}$ such that the poor decide to revolt against any type of dictator, the probability of ending up with a democratic regime after $t$ periods can be shown to be equal to

$$
q_{k}\left(1-\sigma_{k}\right) \sum_{j=0}^{t}\left\{q_{k} \sigma_{k}\right\}^{j}
$$

With $t \rightarrow \infty$, the probability of having democracy converges to $\frac{q_{k}\left(1-\sigma_{k}\right)}{1-q_{k} \sigma_{k}}$ which is strictly positive as long as $q_{k}>0$.Compare now the probability of an individualistic culture (with $\sigma_{k}$ below $\bar{\sigma}_{k}$ ) and the probability of a collectivist culture (with $\sigma_{k}$ above $\bar{\sigma}_{k}$ ) of ending up with democracy as $t \rightarrow \infty$. A country with an individualistic culture will have a higher probability of ending up with democracy than a country with a collectivist culture as long as 


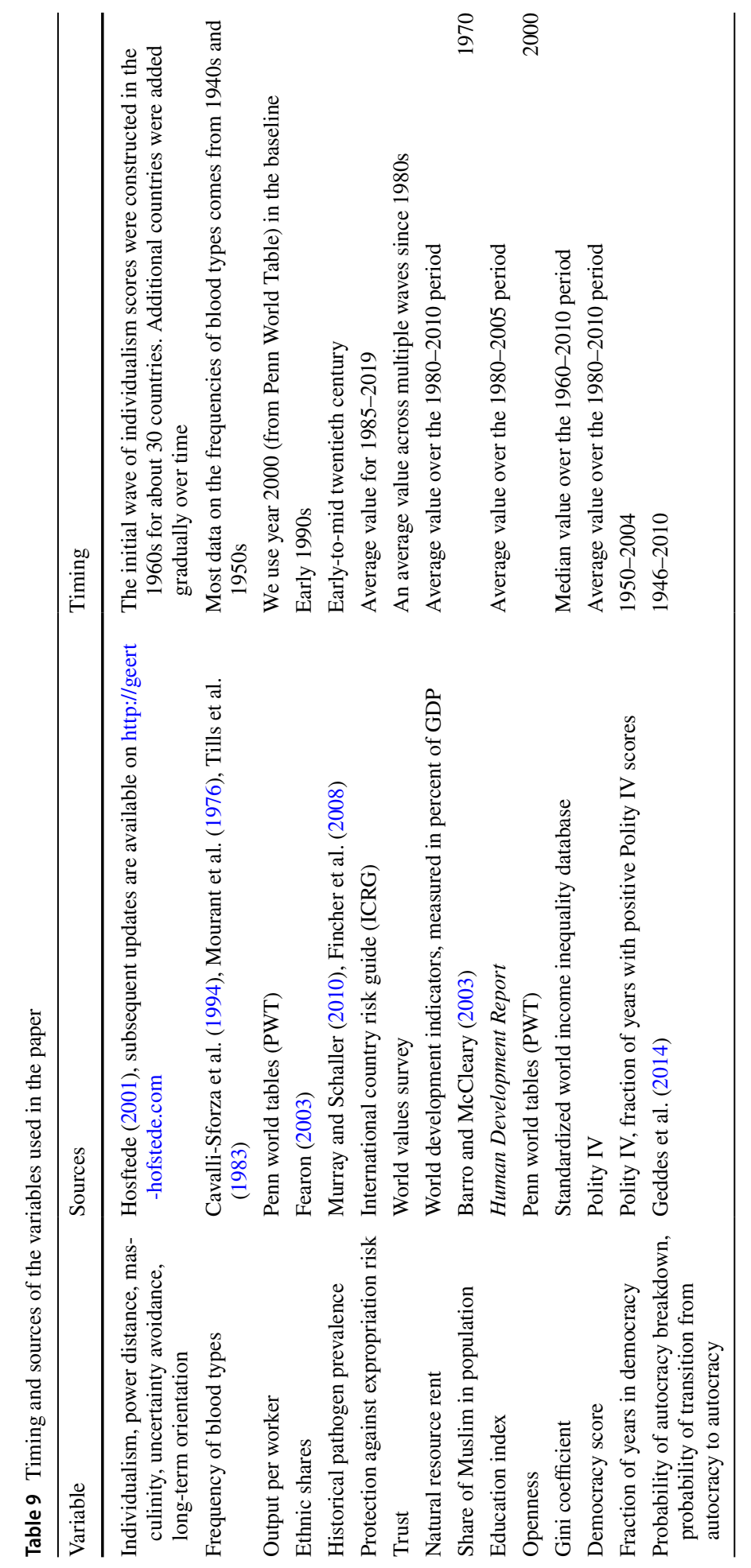


Table 10 Timing of income data

\begin{tabular}{|c|c|c|c|c|c|c|c|}
\hline $\begin{array}{l}\text { Dependent } \\
\text { variable: polity } \\
\text { score }\end{array}$ & (1) & (2) & (3) & (4) & (5) & (6) & (7) \\
\hline Individualism & $\begin{array}{l}0.123 * * * \\
(0.035)\end{array}$ & $\begin{array}{c}0.077 * \\
(0.042)\end{array}$ & $\begin{array}{c}0.087 * \\
(0.045)\end{array}$ & $\begin{array}{l}0.144 * * * \\
(0.032)\end{array}$ & $\begin{array}{l}0.144 * * \\
(0.055)\end{array}$ & $\begin{array}{c}0.130 * \\
(0.066)\end{array}$ & $\begin{array}{l}0.157 * * * \\
(0.055)\end{array}$ \\
\hline $\begin{array}{l}\text { Log income per } \\
\text { worker (PWT, } \\
\text { year 2000) }\end{array}$ & $\begin{array}{l}2.332 * * * \\
(0.771)\end{array}$ & & & & & & \\
\hline \multicolumn{8}{|c|}{ Maddison (2003) historical income per capita } \\
\hline 1900 & & $\begin{array}{c}1.754 \\
(1.645)\end{array}$ & & & & & \\
\hline 1870 & & & $\begin{array}{c}3.066 \\
(1.993)\end{array}$ & & & & \\
\hline 1820 & & & & $\begin{array}{c}3.556 \\
(2.448)\end{array}$ & & & \\
\hline 1700 & & & & & $\begin{array}{c}2.749 \\
(2.447)\end{array}$ & & \\
\hline 1600 & & & & & & $\begin{array}{c}2.929 \\
(2.335)\end{array}$ & \\
\hline 1500 & & & & & & & $\begin{array}{c}2.036 \\
(2.729)\end{array}$ \\
\hline Observations & 91 & 47 & 61 & 51 & 31 & 28 & 31 \\
\hline $\mathrm{R}^{2}$ & 0.423 & 0.469 & 0.411 & 0.440 & 0.573 & 0.421 & 0.559 \\
\hline
\end{tabular}

The dependent variable is the average polity score for the 1980-2010 period from the Polity IV data base. Individualism is Hofstede's index of individualism. A larger value of the index corresponds to a greater level of individualism. Log income per worker: log income (at purchasing power parity) per worker in 2000 from the Penn World Tables. Historical income data are from Angus Maddison's The World Economy. Historical Statistics (Paris: OECD, 2003). Controls low risk of: cross-border conflict, civil disorder, ethnic tensions and war (ICRG, average 1985-2009) are included but not reported. Robust standard errors in parentheses. $* * * p<0.01, * * p<0.05, * p<0.1$

$$
\frac{q_{k}\left(1-\sigma_{k}\right)}{1-q_{k} \sigma_{k}}>\frac{(1-\alpha) q_{k}\left(1-\sigma_{k}\right)}{1-(1-\alpha) q_{k} \sigma_{k}}
$$

One verifies that this inequality is strictly satisfied as long as $\alpha>0$ (Tables 9, 10).

\section{References}

Acemoglu, D., Johnson, S., \& Robinson, J. (2001). The colonial origins of comparative development: An empirical investigation. American Economic Review, 91, 1369-1401.

Acemoglu, D., Johnson, S., Robinson, J., \& Yared, P. (2005). From education to democracy? American Economic Review Papers and Proceedings, 95(2), 44-49.

Acemoglu, D., Johnson, S., Robinson, J., \& Yared, P. (2008). Income and democracy. American Economic Review, 98, 808-842.

Acemoglu, D., Naidu, S., Restrepo, P., \& Robinson, J. (2014). Democracy does cause growth. NBER working paper No 20004. 
Acemoglu, D., \& Robinson, J. (2006). Economic origins of dictatorship and democracy. Cambridge: Cambridge University Press.

Algan, Y., \& Cahuc, P. (2010). Inherited trust and growth. American Economic Review, 100(5), $2060-2092$.

Almond, G., \& Verba, S. (1963). The civic culture. Political attitude and democracy in five nations. New York: Sage Publications.

Barro, R. J., \& Lee, J. W. (2012). A new data set of educational attainment in the world, 1950-2010. New York: mimeo Harvard University.

Barro, R. J., \& McCleary, R. M. (2003). Religion and economic growth across countries. American Sociological Review, 68(5), 760-781.

Bisin, A., \& Verdier, T. (2000). "Beyond the melting pot": Cultural transmission, marriage, and the evolution of ethnic and religious traits. Quarterly Journal of Economics, 115, 955-988.

Bisin, A., \& Verdier, T. (2001). The economics of cultural transmission and the dynamics of preferences. Journal of Economic Theory, 97, 298-319.

Boix, C., \& Stokes, S. (2003). Endogenous democratization. World Politics, 55(4), 517-549.

Bourguignon, F., \& Verdier, T. (2000). Oligarchy, democracy, inequality and growth. Journal of Development Economics, 62(2), 285-313.

Bruckner, M., \& Ciccone, A. (2011). Rain and the democratic window of opportunity. Econometrica, 79(3), 923-947.

Cavalli-Sforza, L. L., Menozzi, P., \& Piazza, A. (1994). The history and geography of human genes. Princeton: Princeton University Press.

Dunning, T. (2008). Crude democracy: Natural resource wealth, and political regimes. Cambridge: Cambridge University Press.

Fearon, J. (2003). Ethnic and cultural diversity by country. Journal of Economic Growth, 8(2), $195-222$.

Fernandez, R., \& Fogli, A. (2006). Fertility: The role of culture and family experience. Journal of the European Economic Association, 4(2-3), 552-561.

Fernandez, R., Fogli, A., \& Olivetti, C. (2004). Mothers and sons: Preference formation and female labor force dynamics. The Quarterly Journal of Economics, 119(4), 1249-1299.

Fincher, C. L., Thornhill, R., Murray, D. R., \& Schaller, M. (2008). Pathogen prevalence predicts human cross-cultural variability in individualism/collectivism. Proceedings-Royal Society. Biological Sciences, 275(1640), 1279-1285.

Finer, S. (1997). The history of government, volumes I-III. Oxford: Oxford University Press.

Fischer, D. H. (1989). Albion's seed: Four British folkways in America. New York: Oxford University Press.

Fish, S. (2002). Islam and authoritarianism. World Politics, 55(1), 4-37.

Fowler, J., Baker, L., \& Dawes, C. (2008). Genetic variation in political participation. American Political Science Review, 102, 233-248.

Freedom House. (1999). Democracy's century: A survey of global political change in the 20th century. Washington: Freedom House.

Geddes, B., Wright, J., \& Frantz, E. (2014). Autocratic breakdown and regime transitions: A new data set. Perspectives on Politics, 12(2), 313-331.

Gorodnichenko, Y., \& Roland, G. (2011). Which dimensions of culture matter for long-run growth? American Economic Review Papers and Proceedings, 101(3), 492-498.

Gorodnichenko, Y., \& Roland, G. (2012). Understanding the individualism-collectivism cleavage and its effects: Lessons from cultural psychology. In M. Aoki, T. Kuran, \& G. Roland (Eds.), Institutions and comparative economic development. London: Palgrave McMillan. (forthcoming).

Gorodnichenko, Y., \& Roland, G. (2017). Culture, institutions and the wealth of nations. Review of Economics and Statistics, 99(3), 402-416.

Griliches, Z., \& Hausman, J. A. (1986). Errors in variables in panel data. Journal of Econometrics, 31(1), 93-118.

Grosjean, P. (2014). A history of violence: the culture of honor as a determinant of homicide in the US South. Journal of the European Economic Association, 12(5), 1285-1316.

Grosjean, P., \& Senik, C. (2011). Democracy, market liberalization and political preferences. Review of Economics and Statistics, 93(1), 365-381.

Guiso, L., Sapienza, P., \& Zingales, L. (2006). Does culture affect economic outcomes. Journal of Economic Perspectives, 20(2), 23-48.

Hatemi, P. K., \& McDermott, R. (2012). The genetics of politics: Discovery, challenges and progress. Trends in Genetics, 28(10), 525-533.

Heine, S. J. (2008). Cultural psychology. New York: W. W Norton \& Company.

Hofstede, G. (2001). Culture's consequences: Comparing values, behaviors, and organizations across nations (2nd ed.). Thousand Oaks: Sage Publications. 
Huntington, S. (1991). The third wave: Democratization in the late twentieth century. Norman: University of Oklahoma Press.

Inglehart, R. (1999). Trust, well-being and democracy. In M. E. Warren (Ed.), Democracy and trust (pp. 88-120). Cambridge: Cambridge University Press.

Inglehart, R. (2002). Culture and democracy. In L. Harrison \& S. Huntington (Eds.), Culture matters: How values shape human progress (pp. 80-97). New York: Basic Books.

Inglehart, R., \& Weizel, C. (2005). Modernization, cultural change and democracy: The human development sequence. Cambridge: Cambridge University Press.

Kornai, J. (2015). Hungary's U-turn: Retreating from democracy. Journal of Democracy, 26(3), 34-48.

Kornai, J. (2016). The system paradigm revisited: Clarification and additions in the light of experiences in the post-socialist region. Acta Oeconomica, 66(4), 547-596.

Kornai, J. (2018). "About the Value of Democracy and other Challenging Research Topics", closing remarks at the conference dedicated to the 90th birthday of János Kornai on 22 February 2018, Corvinus University of Budapest, Budapest.

Lipset, S. M. (1959). Some social requisites of democracy: Economic development and political legitimacy. American Political Science Review, 53, 69-105.

McGuire, M., \& Olson, M. (1996). The economics of autocracy and majority rule: The invisible hand and the use of force. Journal of Economic Literature, 34(1), 72-96.

Mourant, A.E., Kopec, A. C., \& Domaniewska-Sobczak, K. (1976). The distribution of the human blood groups and other polymorphisms. Oxford University Press.

Murray, D. R., \& Schaller, M. (2010). Historical prevalence of infectious diseases within 230 geopolitical regions: A tool for investigating origins of culture. Journal of Cross-Cultural Psychology, 41, 99-108.

Persson, T. (2005). Forms of democracy, policy and economic development. NBER Working Paper No 11171.

Persson, T., \& Tabellini, G. (2009). Democratic capital: The nexus of political and economic change. American Economic Journal: Macroeconomics, 1, 88-126.

Przeworski, A., \& Limongi, F. (1997). Modernization: Theories and facts. World Politics, 49, 155-183.

Putnam, R. D., Leonardi, R., \& Nanetti, R. Y. (1994). Making democracy work: Civic traditions in modern Italy. Princeton: Princeton University Press.

Roland, G. (2004). Understanding institutional change: Fast-moving and Slow-moving institutions. Studies in Comparative International Development, 38, 109-131.

Ross, M. (2001). Does oil hinder democracy? World Politics, 53, 325-361.

Schwartz, S. H. (1994). Beyond individualism/collectivism: New cultural dimensions of values. In K. Uichol, et al. (Eds.), Individualism and collectivism: Theory, method, and applications. Thousand Oaks: Sage.

Schwartz, S. H. (2006). A theory of cultural value orientations: Explication and applications. Comparative Sociology, 5(2-3), 137-182.

Tabellini, G. (2008). Institutions and culture. Journal of the European Economic Association, 6(2-3), 255-294.

Tills, D., Kopec, A. C., \& Tills, R. E. (1983). The distribution of the human blood groups and other polymorphisms. Oxford University Press.

Treisman, D. (2012). Income, democracy and the cunning of reason. New York: mimeo UCLA.

Tullock, G. (1974). The social dilemma: The economics of war and revolution. Blacksburg: University Publications.

Vahabi, M. (2016a). A positive theory of the predatory state. Public Choice, 168(3-4), 153-175.

Vahabi, M. (2016b). The political economy of predation: Manhunting and the economics of escape. Cambridge: Cambridge University Press.

Wantchekon, L. (2002). Why do resource dependent governments have authoritarian governments? Journal of African Finance and Development, 2, 57-77.

Publisher's Note Springer Nature remains neutral with regard to jurisdictional claims in published maps and institutional affiliations. 